\title{
A secretomic view of woody and nonwoody lignocellulose degradation by Pleurotus ostreatus
}

Elena Fernández-Fueyo ${ }^{1}$, Francisco J. Ruiz-Dueñas², María F. López-Lucendo², Marta Pérez-Boada², Jorge Rencoret ${ }^{3}$, Ana Gutiérrez ${ }^{3}$, Antonio G. Pisabarro ${ }^{4}$, Lucía Ramírez ${ }^{4}$ and Angel T. Martínez ${ }^{2}$

\begin{abstract}
Background: Pleurotus ostreatus is the second edible mushroom worldwide, and a model fungus for delignification applications, with the advantage of growing on woody and nonwoody feedstocks. Its sequenced genome is available, and this gave us the opportunity to perform proteomic studies to identify the enzymes overproduced in lignocellulose cultures.

Results: Monokaryotic P. ostreatus (PC9) was grown with poplar wood or wheat straw as the sole C/N source and the extracellular proteins were analyzed, together with those from glucose medium. Using nano-liquid chromatography coupled to tandem mass spectrometry of whole-protein hydrolyzate, over five-hundred proteins were identified. Thirty-four percent were unique of the straw cultures, while only 15 and $6 \%$ were unique of the glucose and poplar cultures, respectively ( $20 \%$ were produced under the three conditions, and additional $19 \%$ were shared by the two lignocellulose cultures). Semi-quantitative analysis showed oxidoreductases as the main protein type both in the poplar (39\% total abundance) and straw (31\%) secretomes, while carbohydrate-active enzymes (CAZys) were only slightly overproduced (14-16\%). Laccase 10 (LACC10) was the main protein in the two lignocellulose secretomes (10-14\%) and, together with LACC2, LACC9, LACC6, versatile peroxidase 1 (VP1), and manganese peroxidase 3 (MnP3), were strongly overproduced in the lignocellulose cultures. Seven CAZys were also among the top-50 proteins, but only CE16 acetylesterase was overproduced on lignocellulose. When the woody and nonwoody secretomes were compared, GH1 and GH3 $\beta$-glycosidases were more abundant on poplar and straw, respectively and, among less abundant proteins, VP2 was overproduced on straw, while VP3 was only found on poplar. The treated lignocellulosic substrates were analyzed by two-dimensional nuclear magnetic resonance (2D NMR), and a decrease of lignin relative to carbohydrate signals was observed, together with the disappearance of some minor lignin substructures, and an increase of sugar reducing ends.
\end{abstract}

Conclusions: Oxidoreductases are strongly induced when P. ostreatus grows on woody and nonwoody lignocellulosic substrates. One laccase occupied the first position in both secretomes, and three more were overproduced together with one VP and one MnP, suggesting an important role in lignocellulose degradation. Preferential removal of lignin vs carbohydrates was shown by 2D NMR, in agreement with the above secretomic results.

Keywords: Pleurotus ostreatus, Secreted proteins, Poplar wood, Wheat straw, LC-MS/MS, Lignin-modifying enzymes, Laccases, Carbohydrate-active enzymes, 2D NMR

\footnotetext{
*Correspondence: atmartinez@cib.csic.es

${ }^{2}$ Centro de Investigaciones Biológicas, CSIC, Ramiro de Maeztu 9,

28040 Madrid, Spain

Full list of author information is available at the end of the article
} 


\section{Background}

Phanerochaete chrysosporium (order Polyporales) has been the model lignin-degrading organism for more than two decades [1]. Due to the interest on lignin degradation/modification-as a key step for the industrial use of plant biomass for the production of cellulose, biofuels, and other chemicals [2] — this fungus was the first basidiomycete whose genome was sequenced [3]. $P$. chrysosporium belongs to the group of wood-rotting basidiomycetes known as white-rot fungi (due to the whitish color of decayed wood after a partial removal of lignin) [4]. More recently, the genomes of other Polyporales were sequenced, such as: (i) Postia placenta [5], as a model causing agent of the so-called brown-rot decay of wood (due to its brownish color after polysaccharide removal) [4]; and (ii) Ceriporiopsis subvermispora [6], a white-rot fungus of biotechnological interest due to its selective degradation of lignin [7]. With the availability of massive sequencing tools, many other Agaricomycotina genomes were sequenced up to a total of 126 available (on 31 September 2015) at the Mycocosm portal (http:// www.genome.jgi.doe.gov/programs/fungi) of the DOE Joint Genome Institute (JGI) [8]. Using this genomic information, several recent studies have discussed the genes involved in lignocellulose decay in saprotrophic basidiomycetes often in combination with transcriptomic and secretomic analyses [9-15], although they were still largely based on Polyporales species.

Pleurotus ostreatus is the second edible mushroom worldwide, just after Agaricus bisporus [16] (two species of the order Agaricales). While Polyporales generally grow on woody substrates, Pleurotus and other members of the Agaricales naturally grow on wood, leaf litter, and/ or other nonwoody lignocellulosic substrates (wood, sawdust, and wheat/rice straw being used for their commercial production). Moreover, some Pleurotus species are able to remove lignin selectively from nonwoody lignocellulosic materials [17], as reported for C. subvermispora growing on wood. These species have been investigated for the biological production of cellulose [18] and biofuels [19] from wheat straw, a largely available plant feedstock for lignocellulose biorefineries [20].

Coprinopsis cinerea [21] and A. bisporus [22, 23], two typical coprophilous and litter/humus decomposers, respectively, and Laccaria bicolor [24], a model mycorrhizogenous fungus, are three additional Agaricales whose genome sequences are available. However, these fungi, and some poor wood decayers recently sequenced [25], are of limited biotechnological interest since their lifestyles do not require a significant degradation/modification of lignin. In contrast, Pleurotus and other Agaricales species are efficient lignin degraders causing white-rot decay of lignocellulosic materials. Therefore, the genome of $P$. ostreatus was sequenced both as an important edible mushroom and as a new model whiterot fungus of the order Agaricales (after P. chrysosporium from Polyporales) being able to grow both on woody and nonwoody lignocellulosic materials. This ability is most probably due to the presence of a new arsenal of lignin-degrading enzymes, as shown after heterologously expressing and characterizing all the ligninolytic peroxidases from the three families mentioned below [26, 27] and two dye-decolorizing peroxidase (DyP) genes from its genome. From 2010, the annotated genome of P. ostreatus is available at JGI as two monokaryons, PC9 (http://www.genome.jgi.doe.gov/PleosPC9_1) and PC15 (http://www.genome.jgi.doe.gov/PleosPC15_2), obtained from a commercial dikaryon [28]. Monokaryotic PC9, showing the highest growth rate, was used in recent transcriptomic [29] and present secretomic studies.

Comparative genomics, ideally combined with biochemical studies, has provided important clues on lignocellulose decay by white-rot and brown-rot saprotrophic basidiomycetes, as well as on host interactions by mycorrhizogenous and pathogenic fungi. Two conclusions of these studies are: (i) the presence of genes of ligninolytic peroxidases - from the lignin peroxidase (LiP), manganese peroxidase $(\mathrm{MnP})$, and/or versatile peroxidase (VP) families - in the genomes of all typical white-rot (i.e., ligninolytic) basidiomycetes and their absence from all the brown-rot (i.e., cellulolytic) fungal genomes, as well as from those of some poor wood rotters; and (ii) the widespread distribution of other genes contributing to the oxidative attack on lignocellulose, such as those of $\mathrm{H}_{2} \mathrm{O}_{2}$-generating oxidases and laccases, in the genomes of wood-rotting basidiomycetes [9, 10, 15, 25, 30]. However, transcriptomic and, especially, secretomic studies are expected to offer the final picture on the enzymatic mechanisms involved in the extracellular decay of lignin, and other lignocellulose constituents, by saprotrophic fungi. Such information has exponentially increased during the last years, as described in a recent review [31]. Interestingly, these studies have shown the variability of enzymes secreted by species with similar genomic contents when growing on the same plant substrates, evidencing the importance of secretomic analyses [32].

In the present study, the secretome of the model whiterot agaric P. ostreatus growing on woody (poplar wood) and nonwoody (wheat straw) lignocellulose was analyzed and compared with that from a glucose medium, with special emphasis on lignin-modifying enzymes (LMEs) and carbohydrate-active enzymes (CAZys). Secreted proteins were identified by nano-liquid chromatography coupled to tandem mass spectrometry (nLC-MS/MS) after trypsin hydrolysis, and their differential production discussed in the context of lignocellulose modification, 
which was analyzed using two-dimensional nuclear magnetic resonance (2D NMR) of the whole lignocellulosic samples at the gel state [33].

\section{Results}

\section{Diversity of $P$. ostreatus proteins in the poplar, straw,} and HAT secretomes

In order to understand the enzymatic mechanisms of lignin and plant polysaccharide degradation by $P$. ostreatus, the secretome of this white-rot (ligninolytic) fungus was analyzed by nLC-MS/MS of the total peptides from trypsin hydrolysis. With this purpose, the fungus (monokaryon PC9) was grown on a woody (poplar chips) and a nonwoody (wheat straw) lignocellulosic substrate (with distilled water as the only additive), and the diversity and relative abundance of the secreted proteins (after 21 days) compared with those found in a glucose medium (HAT). A total of 241, 391, and 206 extracellular proteins were identified in the poplar, wheat straw, and HAT fungal cultures, respectively, as summarized in Fig. 1, where the numbers of unique proteins (i.e., those only detected in one of the secretomes) are indicated together with those shared by the three secretomes or only by two of them (the complete lists of proteins in each of these cultures are included in Additional file 2: Tables S1, S2, S3, respectively).

The different proteins were functionally classified into the following seven types: (i) Oxidoreductases, including LMEs; (ii) CAZys; (iii) Esterases; (iv) Proteases; (v)

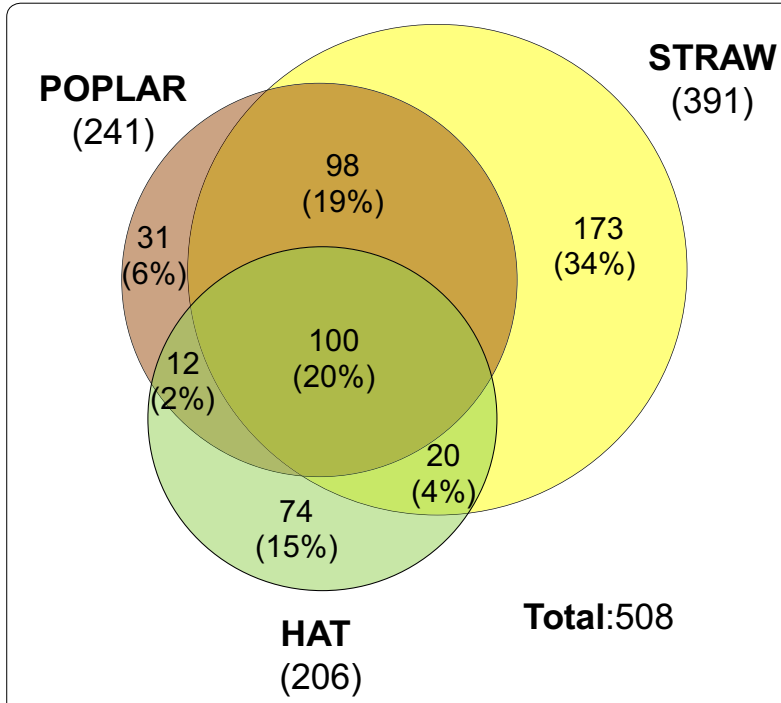

Fig. 1 Venn diagram of total protein numbers in the P. ostreatus poplar, wheat straw, and HAT secretomes. See Fig. 3 for identification of the main (top-50) proteins in the poplar, straw, and HAT (glucose medium) secretomes (and Additional file 2 for the complete protein lists in each of the secretomes)
Phosphatases; (vi) Other function proteins; and (vii) Unknown function proteins. The overall protein composition of the different cultures was similar, in terms of the types present, except for the minor phosphatase group that was absent from the HAT cultures. When the protein numbers in each of the above types were considered, without taking into account the abundance of each of them (see Additional file 1: Figure S1), the highest diversity of CAZy proteins ( $31 \%$ of total proteins) was found in the HAT medium, while more oxidoreductases (21\%) were identified in the lignocellulose cultures. Moreover, $27 \%$ of the wheat straw proteins showed "other" functions (compared with $14 \%$ and $12 \%$ in the HAT and poplar secretomes) and around $20 \%$ of the proteins in each secretome had unknown functions.

\section{Abundance of the main protein types in the three $P$. ostreatus secretomes}

Although $P$. ostreatus produced the same seven protein types in the three media and their diversity (in terms of protein numbers) only showed moderate changes as discussed above (Additional file 1: Figure S1), noteworthy differences were observed when a semi-quantitative analysis of the three secretomes was performed, based on the peptide-spectrum match (PSM) values of each of the proteins identified. As shown in Fig. 2, the relative abundance of oxidoreductases strongly increased from the HAT to the wheat straw and, especially, to the poplar cultures. This took place concomitantly with the marked decreases in the abundance of proteases and "other" proteins, and with a moderate increase of CAZys (the abundance of unknown proteins also increased). Interestingly, laccases are responsible for up to 21 and $14 \%$ of total protein abundances in the poplar and straw cultures, respectively, but only $1 \%$ in the HAT medium, supporting a role in lignocellulose degradation. The same tendency was observed for peroxidases, which were absent from HAT but present on both poplar and wheat straw, albeit with much lower abundances ( $2 \%$ on both substrates) than laccases. In contrast, "other" oxidoreductases, including different oxidases, were significantly more abundant in the HAT (up to $25 \%$ of total protein abundance) than in the poplar and straw cultures (15-16\%).

The abundances of the $508 P$. ostreatus individual proteins strongly varied (from 1 to 566 PSM values). Therefore, a more detailed analysis in the next sections focused on the 50 more abundant (top-50) proteins, whose references (JGI-ID \#), type, predicted function, presence/absence of predicted signal peptide, and abundances (PSM values) are shown in Fig. 3. Although these 50 proteins are a small fraction of the total protein numbers, they represent 62,46 , and $78 \%$ of the total protein abundances in the poplar, straw, and HAT 


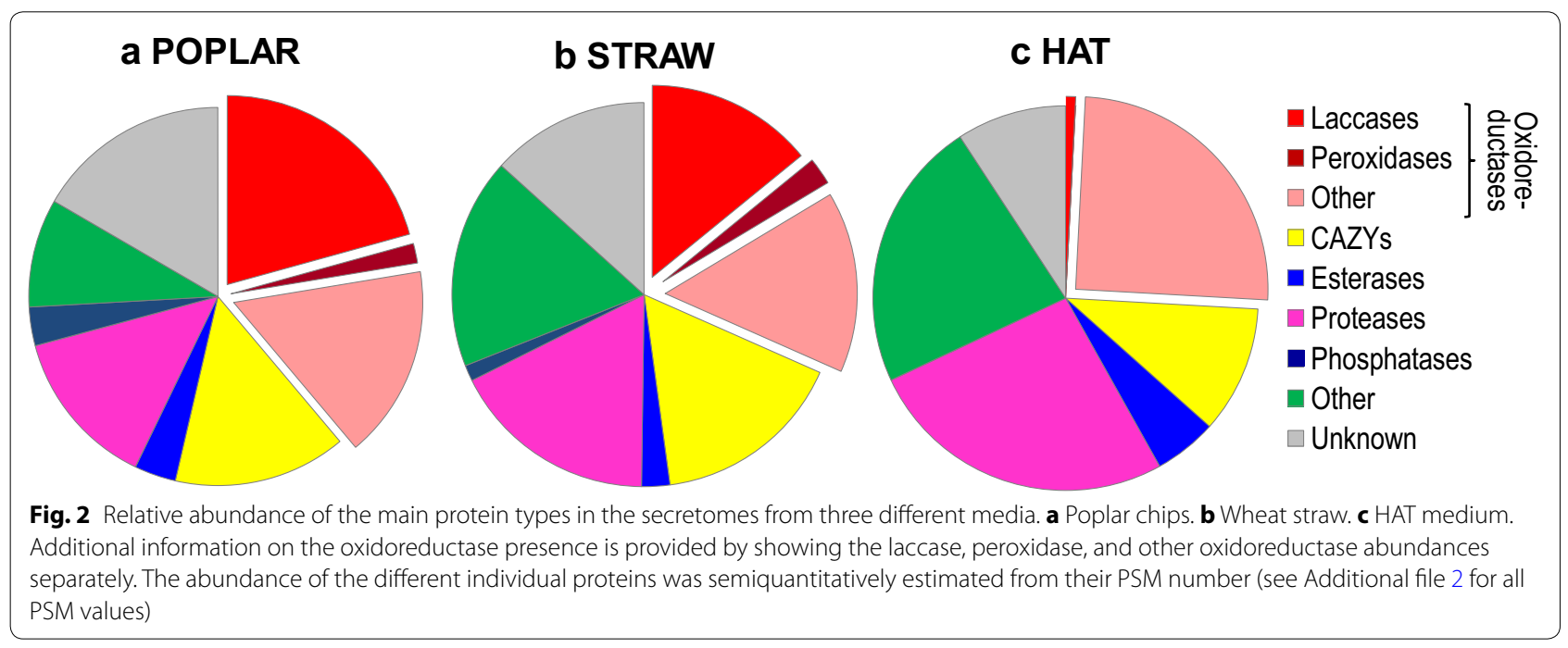

secretomes, respectively. Interestingly, laccases and other LMEs, were among the main proteins in the lignocellulose secretomes. Although CAZys as a group were slightly more abundant in the lignocellulose cultures, the tendency is not general and some of them were more abundant in the HAT medium or did not show strong distribution differences. In the HAT culture, proteases, galactose oxidases, and $\alpha / \beta$-hydrolase were among the most abundant proteins. Nonetheless, proteins with unknown function represented an important fraction of the top-50 proteins. The radical differences between the secretome from the HAT and lignocellulose cultures are illustrated in Fig. 4, where the relative abundances of the (14) main individual proteins discussed below are compared.

\section{P. ostreatus CAZys}

CAZys are involved in the synthesis, metabolism, and transport of carbohydrates. Twenty-six percent of the 112 CAZy proteins identified were present in the three P. ostreatus secretomes, $16 \%$ were shared by the poplar wood and wheat straw secretomes, and much lower numbers were shared by the poplar-HAT $(4 \%)$ and straw-HAT (7 \%) secretomes (Additional file 1: Figure S2A). Finally, the HAT and wheat straw secretomes had higher number of unique CAZys (19-20\%) than the poplar secretome (only $8 \%$ ).
When CAZy classification was considered, 38, 38, and 33 different families were identified in the secretome of $P$. ostreatus growing on poplar, wheat straw, and HAT, respectively, up to a total of 47 families (Fig. 5). Glycoside hydrolases (GHs) were the most widespread group of CAZys (with 26/27/21 families in the poplar/ wheat-straw/HAT secretomes), followed by carbohydrate-binding modules (CBMs; with 7/6/7 families) and carbohydrate esterases (CEs; with 4/3/5 families). Finally, one polysaccharide lyase (PL) family was identified in the two lignocellulose cultures (not in HAT), and one glycosyltransferase (GT) family on wheat straw. Differences in the number of proteins in each CAZy family were observed with up to: (i) four GH5 and GH31 proteins in the poplar secretome; (ii) four GH18 and five $\mathrm{GH} 3$ proteins in the wheat straw secretome; and (iii) four GH5, GH7, GH16, and GH18, and six CE4 proteins in the HAT secretome. This can be related to duplication of GH7 (16 copies), GH16 (at least 14 copies), GH3 (11 copies), GH18 (at least 10 copies), CE4 (10 copies), and GH5 (eight copies) genes in the P. ostreatus genome [15, 25].

The $P$. ostreatus secretomes not only differed in the CAZy diversity but also in their relative abundance as shown in Fig. 6 for the best represented proteins, most of them belonging to GH families (for all the CAZy proteins detected in the three secretomes, see Additional file 2). Among these proteins, we found two members of

(See figure on next page.)

Fig. 3 Fifty more abundant (top-50) proteins in the secretome of P. ostreatus growing on three different media. Semi-quantitative analysis based on PSM (peptide-spectrum match) values in the poplar, straw, and HAT (glucose medium) secretomes. The presence/absence of a predicted signal peptide (SP) is also indicated for the different proteins. The protein reference numbers, here and in the rest of the study and Additional file 2, correspond to the JGI Gene Catalog for P. ostreatus PC9. Abbreviations for protein types: CAZy carbohydrate-active proteins; Este esterases; Othe proteins with other functions; Oxid oxidoreductases; Phos phosphatases; Prot proteases; Unkn unknown function proteins 


\begin{tabular}{|c|c|c|c|c|c|c|}
\hline JGI-ID\# & SP & Type & Predicted protein function & Poplar & Straw & HAT \\
\hline 81117 & + & Oxid & LACC10 (=POXC/POX2) & 557 & 459 & 6 \\
\hline 134564 & + & Oxid & Galactose oxidase & 232 & 105 & 462 \\
\hline 71759 & + & Prot & S8 and S53 peptidase & 0 & 0 & 566 \\
\hline 60171 & + & Prot & Peptidase S8 & 210 & 250 & 59 \\
\hline 132884 & - & Othe & $\alpha / \beta$-Hydrolase & 0 & 0 & 457 \\
\hline 101121 & + & Othe & $\beta-1,6-\mathrm{N}-$ Acetylglucosaminyltransferase & 65 & 0 & 288 \\
\hline 93022 & - & Prot & Aspartic-type endopeptidase & 12 & 7 & 328 \\
\hline 116143 & + & Oxid & LACC2 (=POXA3) & 163 & 79 & 41 \\
\hline 84016 & + & Este & Carboxylesterase & 8 & 5 & 253 \\
\hline 94009 & - & Oxid & Galactose oxidase & 0 & 0 & 241 \\
\hline 83417 & + & Unkn & Unknown & 20 & 7 & 209 \\
\hline 52745 & + & Prot & Metalloprotease & 6 & 19 & 210 \\
\hline 100586 & + & Oxid & FAD linked oxidase & 8 & 3 & 213 \\
\hline 124117 & + & CAZy & GH15 & 47 & 42 & 134 \\
\hline 81107 & + & Oxid & LACC9 (=POX1) & 94 & 84 & 0 \\
\hline 115072 & + & Othe & $\alpha / \beta$-Hydrolase & 0 & 0 & 177 \\
\hline 75940 & + & Othe & $\alpha / \beta$-Hydrolase & 57 & 90 & 7 \\
\hline 132167 & - & Unkn & Unknown & 107 & 36 & 9 \\
\hline 99622 & - & Unkn & Unknown & 81 & 66 & 0 \\
\hline 88568 & + & CAZy & GH47 & 65 & 46 & 22 \\
\hline 110973 & - & Unkn & Unknown & 42 & 71 & 19 \\
\hline 98389 & - & Othe & $\beta-1,6-\mathrm{N}$-Acetylglucosaminyltransferase & 24 & 4 & 96 \\
\hline 71759 & + & Prot & S8 and S53 peptidase & 29 & 92 & 0 \\
\hline 88522 & - & Phos & Phosphatidylserine decarboxylase & 95 & 14 & 0 \\
\hline 62728 & + & Este & Lipase & 85 & 23 & 0 \\
\hline 74226 & + & Unkn & Unknown & 25 & 12 & 64 \\
\hline 83972 & + & Prot & Peptidase S10 & 25 & 39 & 34 \\
\hline 84329 & + & Prot & Subtilase & 33 & 60 & 4 \\
\hline 91073 & + & Prot & Metalloproteases (“zincins”) & 30 & 29 & 36 \\
\hline 137740 & + & Oxid & $\mathrm{MnP} 3$ & 45 & 49 & 0 \\
\hline 98024 & - & CAZy & GH3 & 9 & 66 & 19 \\
\hline 98428 & + & Unkn & Unknown & 47 & 30 & 15 \\
\hline 137757 & + & Oxid & VP1 & 47 & 35 & 9 \\
\hline 57949 & + & Prot & Peptidase S28 & 11 & 12 & 68 \\
\hline 91123 & + & Oxid & FAD oxidoreductase of $\mathrm{CH}-\mathrm{OH}$ groups & 0 & 0 & 86 \\
\hline 113478 & + & Othe & Aldose 1-epimerase & 0 & 1 & 83 \\
\hline 107625 & + & Prot & Zn-Dependent exopeptidases & 2 & 10 & 68 \\
\hline 115209 & + & CAZy & GH76 & 24 & 26 & 29 \\
\hline 90832 & + & CAZy & GH1 & 43 & 16 & 18 \\
\hline 70033 & + & Prot & Aspartic-type endopeptidase & 9 & 23 & 45 \\
\hline 82945 & + & Othe & Concanavalin A-like lectins/glucanases & 30 & 14 & 29 \\
\hline 81104 & + & Oxid & LACC6 (=POXA1b) & 22 & 47 & 2 \\
\hline 96445 & + & CAZy & CE16 & 37 & 33 & 0 \\
\hline 47522 & + & CAZy & GH105 & 17 & 23 & 29 \\
\hline 121882 & + & Oxid & GMC & 2 & 2 & 64 \\
\hline 130566 & + & Oxid & GMC & 0 & 0 & 64 \\
\hline 88371 & + & Prot & Peptidase & 0 & 34 & 30 \\
\hline 117693 & - & Oxid & Aldo/keto reductase & 19 & 44 & 0 \\
\hline 117204 & - & Oxid & DyP4 & 7 & 21 & 33 \\
\hline \multirow[t]{3}{*}{115427} & + & Unkn & Unknown & 14 & 40 & 7 \\
\hline & & & Top-50 (total PSM/proteins) & $2493 / 42$ & $2168 / 43$ & $4633 / 42$ \\
\hline & & & Whole secretomes (total PSM/proteins) & $4021 / 241$ & $4730 / 391$ & $5966 / 206$ \\
\hline
\end{tabular}




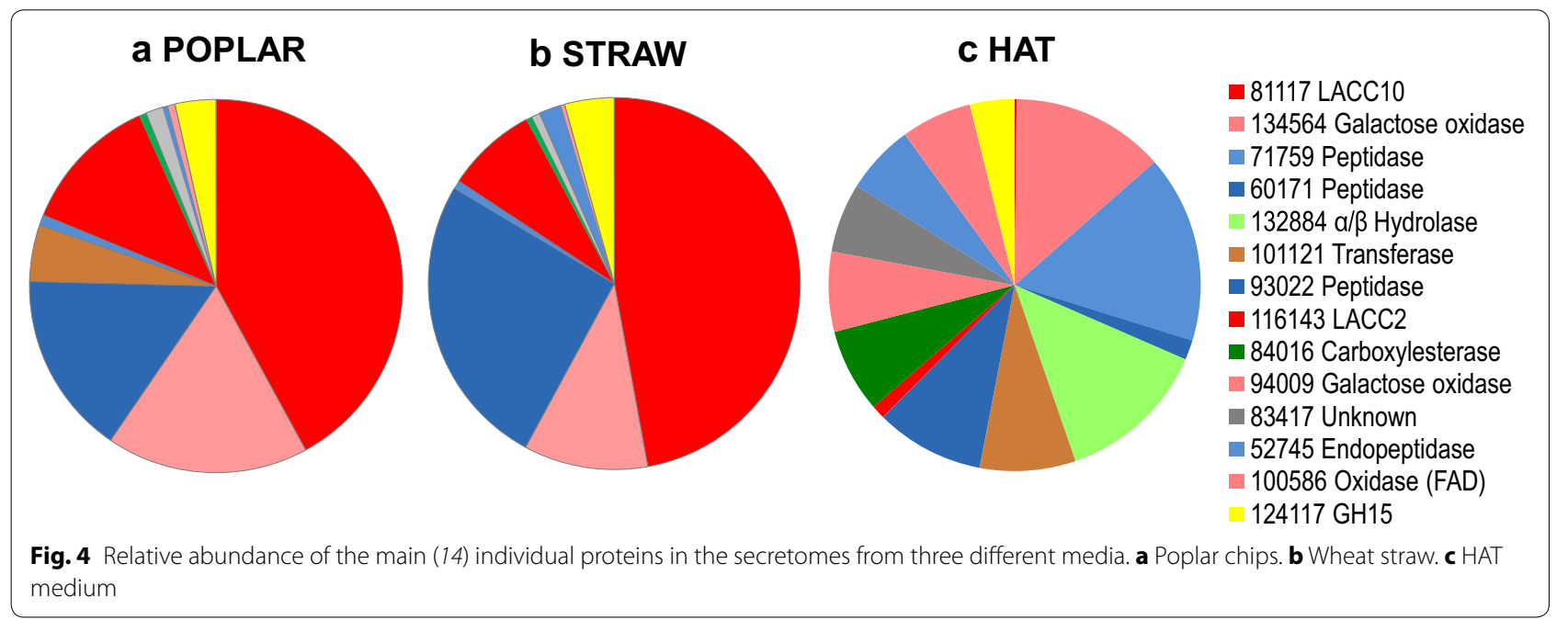

the GH3 family (JGI \# 61232 and 98024), which exhibit $\beta$-glucosidase $/ \beta$-xylosidase activities, and two members of the GH47 family (JGI-ID\# 61416 and 88568), which exhibit $\alpha$-mannosidase activity. GH3-98024 was the most abundant CAZy protein in wheat straw $(1.4 \%$ of total proteins) while it was less represented in the HAT and poplar cultures; and GH3-61232 showed a similar distribution. On the other side, GH47-88568 was the most abundant CAZy in poplar (1.6 \% of total proteins) while it was less represented in the straw and HAT cultures, and a similar distribution was observed for GH47-61416. Moreover, the GH15 family, which includes glucoamylase activity, was represented by JGI-ID\# 124117, the most abundant CAZy protein among the top-50 proteins (Fig. 3). In contrast with the other CAZys mentioned above, GH15-124117 showed the highest abundance in the HAT medium $(2.2 \%$ of total proteins). Proteins of families GH1 (including $\beta$-glycosidase activities), GH18 (including chitinase activity), GH31 (including $\alpha$-glycosidase activities), GH51 (including endoglucanase/xylanase activities), GH76 ( $\alpha$-1,6-mannanase activity), and GH105 (unsaturated rhamnogalacturonyl/ glucuronyl hydrolase activities) were also among the best represented members of the $\mathrm{GH}$ family.

Other CAZy groups also include well-represented proteins in the P. ostreatus secretomes, such as: (i-ii) families CE16 (showing acetylesterase activity; with JGI-ID\# 96445) and PL8 (including hyaluronate lyase activity; with JGI-ID\# 53101) only detected in the poplar and wheat straw cultures; and (iii) family CBM13 with JGIID\# 116255 present in the three secretomes.

\section{P. ostreatus LMEs and peroxide-providing auxiliary oxidoreductases}

The ligninolytic system of white-rot fungi includes extracellular laccases (phenol oxidases, POX), heme peroxidases, and oxidases generating hydrogen peroxide from the glucose/methanol/choline oxidase/dehydrogenase (GMC) and copper radical oxidase (CRO) superfamilies. However, only laccases and heme peroxidases of the LiP, MnP, and VP families are recognized as LMEs. The above oxidoreductases have been considered as auxiliary enzymes in CAZy families AA1 (laccases), AA2 (peroxidases), AA3 (GMC oxidases/dehydrogenases), and AA5 (CRO oxidases), respectively [34], but the term auxiliary enzymes is reserved here for the oxidases that provide the hydrogen peroxide required by ligninolytic peroxidases. Seventeen percent of the 103 oxidoreductase proteins identified were detected in the three P. ostreatus secretomes. Additionally, $27 \%$ were shared by the poplar and wheat straw secretomes, and the HAT secretome only shared $2 \%$ proteins with each of the lignocellulose secretomes (Additional file 1: Figure S2B). Finally, as in the case of CAZys, the wheat straw and HAT secretomes had higher numbers of unique oxidoreductases (32 and $14 \%$, respectively) than the poplar secretome (only $5 \%$ ).

As shown in Fig. 7, LMEs were extremely abundant in the poplar ( $23 \%$ of total protein abundance) and wheat straw (16\%) secretomes, while they were barely present in the HAT medium (only $1 \%$ ). Four laccase (LACC) proteins-LACC10 (JGI-ID\# 81117), LACC2 (JGI-ID\# 116143), LACC9 (JGI-ID\# 81107), and LACC6 (JGI-ID\# 81104 ) - were among the top-50 proteins (Fig. 3) with LACC10 occupying the first position due to its high abundance in the poplar/straw cultures (13.9/9.7\%). The poplar/wheat-straw abundances of LACC2 (4.0/1.6\%), LACC9 (2.3/1.8\%), and LACC6 (0.5/1.0 \%) were also comparatively high. The four laccases showed similar abundances in the two lignocellulosic secretomes, with LACC9 being absent from the HAT cultures (Additional file 2). 


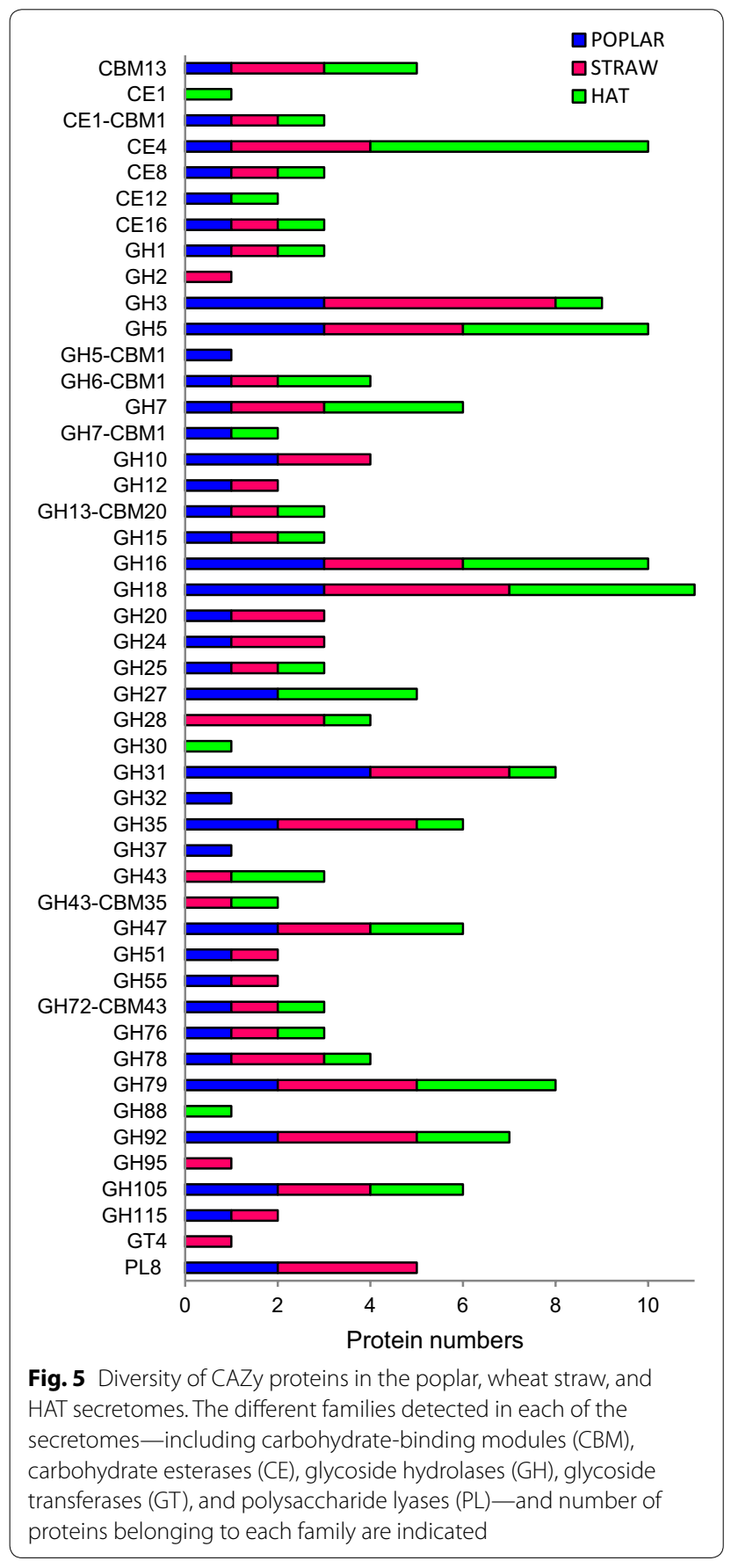

Regarding class-II peroxidases, MnP3 (JGI-ID\# 137740) and VP1 (JGI-ID\# 137757) were the most abundant proteins, included in the top-50 (Fig. 3), although their relative abundances in the lignocellulose cultures (1.0-1.1 and $0.7-1.2 \%$, respectively) were largely below those of the four laccases. MnP6 (JGI-ID\# 51713), VP2 (JGI-ID\# 137766), and VP3 (JGI-ID\# 123383) were also detected in the two lignocellulose cultures, with low abundances $(0.3$,
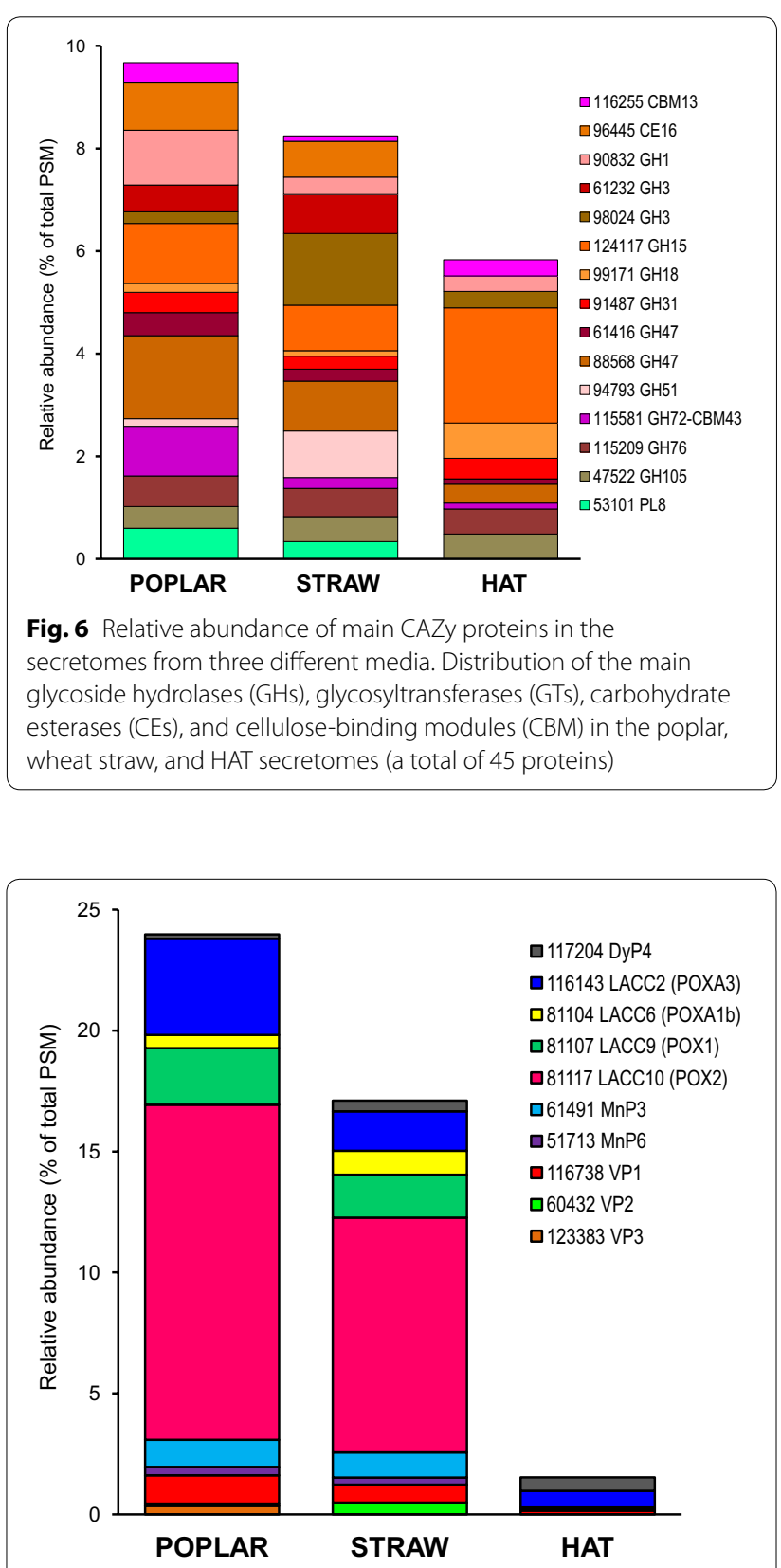

Fig. 7 Relative abundance of main LMEs (peroxidases and laccases) in the secretomes from three different media. Distribution of the main peroxidases and laccases in the poplar, wheat straw, and HAT secretomes (a total of 11 proteins)

$0.1-0.5$, and $0-0.3 \%$, respectively). Only VP1 was identified in the HAT medium, although as a minor protein. DyPs contribute to degradation of lignin products, and P. ostreatus DyP4 (JGI-ID\# 117204) was one of the few LME proteins in the HAT medium ( $0.6 \%$ abundance), being also detected on poplar and wheat straw (Fig. 3).

Several oxidases would act synergistically with LME, providing the hydrogen peroxide required by peroxidases 
or reducing aromatic radicals formed by laccases. Among them, aryl-alcohol oxidase (AAO) was detected in the three secretomes (Additional file 2) but it was not among the top-50 proteins. Another two members of the GMC superfamily (JGI-ID\# 121882 and 130566), and two related flavooxidases (JGI-ID\# 100586 and 91123), were well represented in the HAT culture (1.1, 1.1, 3.6, and $1.4 \%$ of all the proteins, respectively) (Fig. 3) but nearly absent from the lignocellulose cultures. In a similar way, two galactose oxidases (JGI-ID\# 134564 and 94009) were among the main proteins in the HAT medium (7.7 and $4.0 \%$, respectively) being also present in the lignocellulose cultures (2.2-5.8 and $0 \%$, respectively).

\section{Other secreted proteins}

Together with oxidoreductases and CAZys, proteases are another main type of proteins in the $P$. ostreatus secretomes, included among the top-50 (Fig. 3). Some of the main proteases showed a markedly differential distribution, with JGI-ID\# 71759 being the most abundant protein in the HAT secretome $(9.5 \%)$ but completely absent from the lignocellulose cultures. The same was observed for a carboxylesterase (JGI-ID\# 84016) with 32and 50-fold lower relative abundance in the poplar and straw secretomes than in the HAT secretome, respectively. However, the opposite tendency was exhibited by three additional proteases (JGI-ID\# 60171, 93022, and 52745) with much higher (4/4-, 27/47-, and 35/11-fold higher, respectively) abundances on poplar/wheat-straw than in the HAT medium.

Among those classified as "other", three $\alpha, \beta$-hydrolases were in the top-50 (Fig. 3), with two of them (JGIID\# 132884 and 115072) being exclusive of the HAT secretome (132884 being the third more abundant protein in this culture), and the third one (JGI-ID\# 75940) showing higher abundance in the lignocellulose cultures.
Finally, differences were also observed in the main unknown proteins, with some of them being significantly more abundant in the lignocellulose cultures (such as JGI-ID\# 132167 and 99622, with $2.7 \%$ relative abundance) and others in the HAT medium (such as JGI-ID\# 83417 , attaining $3.5 \%$ ).

\section{Lignocellulose modification as shown by 2D NMR}

Structural analysis of the whole wood and straw samples, without the need for previous isolation of the lignin and polysaccharide fractions, was possible by swelling the milled material in deuterated dimethylsulfoxide (DMSO$d_{6}$ ) giving a gel-like material, which was directly analyzed under liquid 2D NMR conditions in heteronuclear singlequantum correlation (HSQC) experiments. The NMR spectra of the treated poplar wood and wheat straw are shown in Fig. 8b, d, while those of the corresponding uninoculated controls are shown in Fig. 8a, c. The formulae of the different structures identified are included in the bottom of Fig. 8 .

The aromatic/unsaturated region of the spectra $\left(\delta_{\mathrm{C}} /\right.$ $\delta_{\mathrm{H}}$ 90-150/6-8 ppm) included the different correlations of the lignin: (i) p-hydroxyphenyl units $(\mathrm{H}$, blue), only detected in the wheat straw; (ii) guaiacyl units (G, green); (iii) normal syringyl units (S, red); and (iv) $\mathrm{C} \alpha$-oxidized syringyl units (S, red), only detected in the poplar wood. Other aromatic/olefinic correlations corresponded to $p$-hydroxybenzoic acid (PB, magenta) in the poplar wood spectra, and tricin ( $\mathrm{T}$, brown), ferulic acid (FA, orange), and $p$-coumaric acid (PCA, light brown) in the wheat straw spectra. On the other hand, the aliphatic-oxygenated region of the spectra $\left(\delta_{\mathrm{C}} / \delta_{\mathrm{H}}\right.$ $50-120 / 3-5 \mathrm{ppm}$ ) included the correlations of lignin side chains forming different substructures, such as: (i) $\beta-\mathrm{O}-4^{\prime}$ ethers (A dark blue); (ii) phenylcoumarans ( $\mathrm{B}$, turquoise); and (iii) resinols $(\mathrm{C}$, purple). This region also includes

(See figure on next page.)

Fig. 8 2D NMR of poplar wood $(\mathbf{a}, \mathbf{b})$ and wheat straw $(\mathbf{c}, \mathbf{d})$ treated with P. ostreatus $(\mathbf{b}, \mathbf{d})$ and controls $(\mathbf{a}, \mathbf{c})$. The formulae of the lignin and cinnamic acid structures, whose correlation signals are identified in the different spectra, are shown in the bottom of the figure: $A \beta-O-4^{\prime}$ ether (dark blue); $B$ phenylcoumaran (turquoise); C resinol (purple); PCA p-coumaric acid (light brown); FA ferulic acid (orange); PB p-hydroxybenzoate (pink); $T$ tricin (brown); H p-hydroxyphenyl unit (blue); G guaiacyl unit (green); $S$ syringyl unit (red); $S^{\prime}$ a-oxidized syringyl unit (red). The prominent methoxyl signal ( $\mathrm{MeO}$, yellow) is also shown in the spectra, together with some selected carbohydrate correlation $\left(\mathrm{C}_{1}-\mathrm{H}_{1}, \mathrm{C}_{2}-\mathrm{H}_{2}\right.$, and $\left.\mathrm{C}_{3}-\mathrm{H}_{3}\right)$ signals (cyan) corresponding to normal and acetylated xylan ( $\mathrm{X}$ and $\mathrm{X}^{\prime}$, respectively), uronic acid $(\mathrm{U})$, arabinan ( $\mathrm{Ar}$ ), and glucan units ( $\mathrm{Gl}$ ), a and $\beta$ reducing ends in xylan $\left(\alpha X_{1(R)}\right.$ and $\beta X_{1(R)}$, respectively). List of lignin (and related) signals $\left(\delta_{C} / \delta_{H} p p m\right): 53.2 / 3.46, C_{\beta} / H_{\beta}$ in phenylcoumarans $\left(B_{\beta}\right) ; 53.6 / 3.05, C_{\beta} / H_{\beta}$ in resinols $\left(C_{\beta}\right) ; 55.5 / 3.66, C / H$ in methoxyls $(-O M e) ; 71.1 / 4.16$ and 3.77, $C_{\gamma}-H_{\gamma}$ in $\beta-\beta^{\prime}$ resinols $\left(C_{\gamma}\right) ; 71.1-71.5 / 4.72-4.85, C_{\alpha} / H_{\alpha}$ in $\beta-O-4^{\prime}$ ethers $\left(A_{\alpha}\right)$; 84.1/4.24, $C_{\beta} / H_{\beta}$ in $\beta-O-4^{\prime}$ linked to a $G$ unit $\left(A_{\beta(G)}\right) ; 84.9 / 4.59, C_{\alpha} / H_{\alpha}$ in $\beta-\beta^{\prime}$ resinols $\left(C_{\alpha}\right) ; 86.0 / 4.08, C_{\beta} / H_{\beta}$ in $\beta-O-4^{\prime}$ ethers linked to a $S$ unit $\left(A_{\beta(S)}\right)$; 86.7/5.41, $\mathrm{C}_{\alpha} / \mathrm{H}_{a}$ in phenylcoumarans $\left(\mathrm{B}_{\alpha}\right) ; 94.2 / 6.56, \mathrm{C}_{8} / \mathrm{H}_{8}$ in tricin $\left(\mathrm{T}_{8}\right) ; 98.9 / 6.23, \mathrm{C}_{6} / \mathrm{H}_{6}$ in tricin $\left(\mathrm{T}_{6}\right) ; 103.8 / 6.68, \mathrm{C}_{2} / \mathrm{H}_{2}$ and $\mathrm{C}_{6} / \mathrm{H}_{6}$ in syringyl units $\left(\mathrm{S}_{2,6}\right) ; 104.1 / 7.30, \mathrm{C}_{2^{\prime}, 6^{\prime}} / \mathrm{H}_{2^{\prime}, 6^{\prime}}$ in tricin $\left(\mathrm{T}_{2^{\prime}, 6^{\prime}}\right) ; 104.7 / 7.03, \mathrm{C}_{3} / \mathrm{H}_{3}$ in tricin $\left(\mathrm{T}_{3}\right) ; 106.2 / 7.29, \mathrm{C}_{2} / \mathrm{H}_{2}$ and $\mathrm{C}_{6} / \mathrm{H}_{6}$ in a-oxidized syringyl units $\left(\mathrm{S}_{2,6}^{\prime}\right) ; 110.7 / 6.93, \mathrm{C}_{2} /$ $\mathrm{H}_{2}$ in guaiacyl units $\left(\mathrm{G}_{2}\right) ; 111.0 / 7.28, \mathrm{C}_{2} / \mathrm{H}_{2}$ in ferulic acid $\left(\mathrm{FA}_{2}\right) ; 1$ 14.0/6.40, $\mathrm{C}_{\beta} / \mathrm{H}_{\beta}$ in $p$-coumaric acid $\left(\mathrm{PCA}_{\beta}\right) ; 114.9 / 6.75, \mathrm{C}_{3,5} / \mathrm{H}_{3,5}$ in $p$-hydroxybenzoic acid $\left(\mathrm{PB}_{3,5}\right) ; 115.0 / 6.58-7.00, \mathrm{C}_{5 / 6} / \mathrm{H}_{5 / 6}$ in guaiacyl units $\left(\mathrm{G}_{5 / 6}\right) ; 118.9 / 6.75, \mathrm{C}_{6} / \mathrm{H}_{6}$ in guaiacyl units $\left(\mathrm{G}_{6}\right) ; 123.3 / 7.11, \mathrm{C}_{6} / \mathrm{H}_{6}$ in ferulic acid $\left(\mathrm{FA}_{6}\right) ; 127.8 / 7.18$, $\mathrm{C}_{2,6} / \mathrm{H}_{2,6}$ in $p$-hydroxyphenyl units $\left(\mathrm{H}_{2,6}\right) ; 130.1 / 7.50, \mathrm{C}_{2,6} / \mathrm{H}_{2,6}$ in $p$-coumaric acid $\left(\mathrm{PCA}_{2,6}\right) ; 131.2 / 7.65, \mathrm{C}_{2,6} / \mathrm{H}_{2,6}$ in $p$-hydroxybenzoic acid $\left(\mathrm{PB}_{2,6}\right) ;$ and 145.2/7.56, $\mathrm{C}_{\alpha} / \mathrm{H}_{a}$ in $p$-coumaric acid and ferulic acid $\left(\mathrm{PCA}_{a}\right.$ and $F \mathrm{~A}_{a}$ ). Additional signals (in cyan) correspond to selected correlations of carbohydrate xylose $(X)$, including $\alpha / \beta$ reducing ends $\left(X_{(R)}\right)$, acetylated xylose $\left(X^{\prime}\right)$, arabinose $(A r)$, glucose $(G l)$, and uronic acid $(U)$ units (unassigned carbohydrate signals are in gray) 

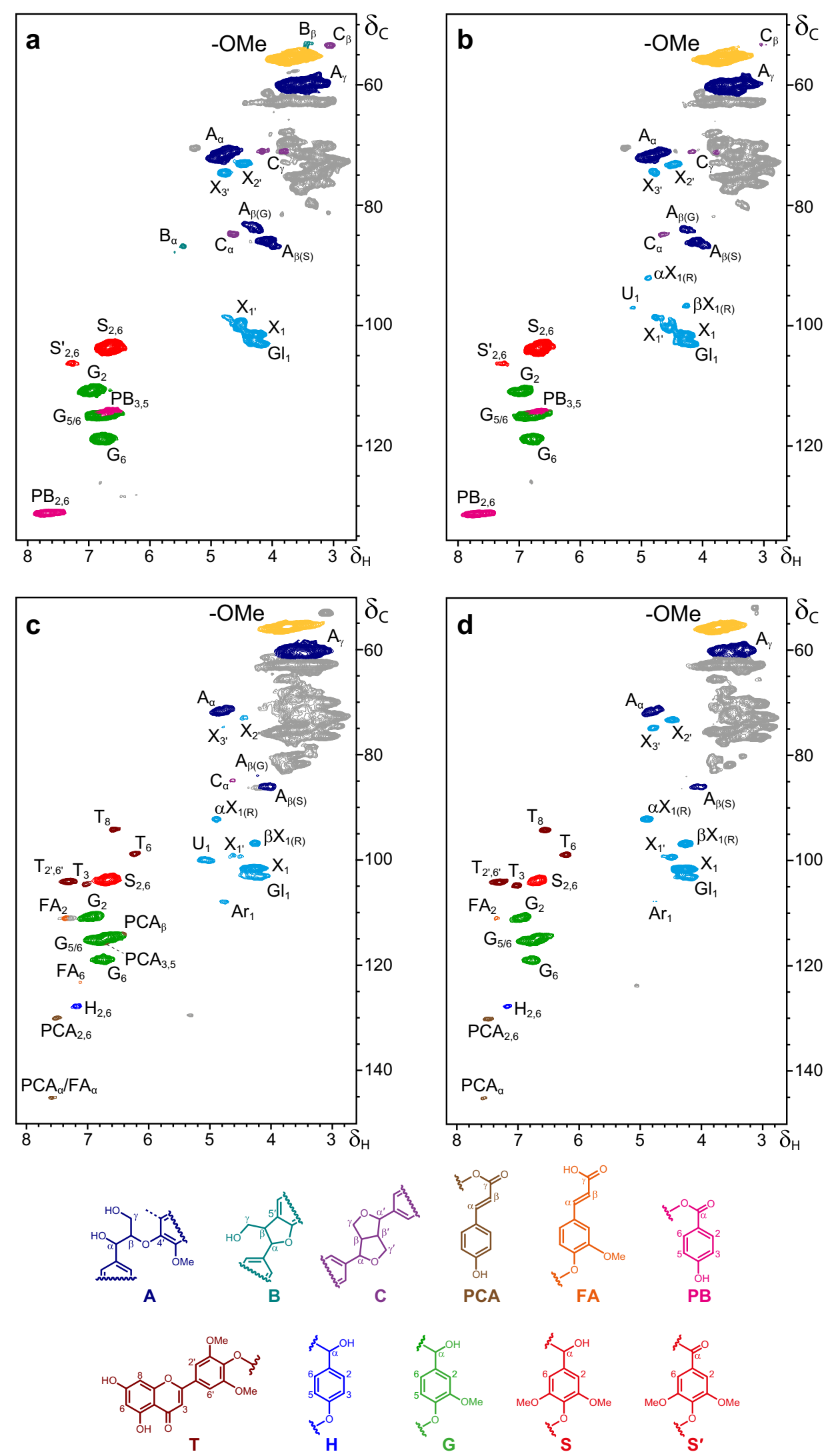
the carbohydrate correlations of hemicellulose, since cellulose is silent under the present conditions. Among them, the anomeric carbon $\left(C_{1}\right)$ signals of normal and acetylated xylose ( $\mathrm{X}$ and $\mathrm{X}^{\prime}$, respectively), arabinose (Ar), glucose $(\mathrm{Gl})$, and uronic acid (U) units are indicated in cyan (including $\alpha$ - and $\beta$-xylose reducing ends), together with those of $C_{2} / C_{3}$-acetylated xylose units, while all the other carbohydrate correlations were not assigned on the spectra (gray). Finally, the prominent correlation of lignin methoxyls is also observed (OMe, yellow) in this region.

During the 21-day growth of $P$. ostreatus on poplar wood or wheat straw (resulting in 7-10\% weight loss with respect to the controls) some modification of the remaining lignocellulosic material was produced, as shown by 2D NMR of the treated samples and controls. The first observation from this comparison is the increased ratio between carbohydrate (estimated from the anomeric carbon signals) and lignin (estimated as the total H, G, S, and $S$ ' signals) in poplar wood (from 1.2 to 1.6 ) and, especially, in wheat straw (from 3.0 to 4.9 ) revealing a preferential degradation of lignin. The differential decrease of lignin and carbohydrate signals agrees with the strongest decrease of (Klason) lignin in wheat straw (from 22 to $12 \%$, after deducting ashes). Monosaccharide analysis in the Klason hydrolyzates only revealed slight changes of the glucose/mannose/xylose/arabinose/galactose percentages in the treated wood (71.9/13.9/7.7/4.9/1.6) and straw $(66.0 / 11.6 / 11.2 / 9.9 / 1.3)$ with respect to the corresponding controls (72.8/13.8/7.4/4.7/1.4 and $65.2 / 11.1 / 11.1 / 10.5 / 2.2$, respectively). Simultaneously with the relative decrease of lignin, the amount of $p$-hydroxybenzoic acid per 100 lignin units increased in the treated poplar wood.

The modest delignification of poplar wood was accompanied by a low structural modification of the remaining lignin (and other wood components). In this way, the $\mathrm{H}: \mathrm{G}: \mathrm{S}: \mathrm{S}^{\prime}$ ratio passed from 0:48:50:2 in the control to 0:46:54:1 in the treated wood, and the percentage of syringol and phenylcoumaran substructures per 100 lignin units passed from 6 to $4 \%$ and from 2 to $0 \%$, respectively, while that of $\beta-\mathrm{O}-4^{\prime}$ ethers remains practically unchanged. However, the higher decrease of the lignin signals in wheat straw was accompanied by stronger modifications of: (i) the residual lignin H:G:S:S' ratio, which passed from 3:57:40:0 in the control to 5:62:33:0 in the treated wheat straw; and (ii) the percentage of resinol substructures per 100 lignin units passed from 1.6 to $0 \%$, while that of $\beta-\mathrm{O}-4^{\prime}$ ethers was less significantly modified (no phenylcoumarans were found in wheat straw). Interestingly, the two $p$-hydroxycinnamic acids present in wheat straw were differentially degraded, and the ferulic content decreased (from 12 to $6 \%$ of the lignin content) while the $p$-coumaric content increased (from 2 to $5 \%$ of the lignin content). Finally, the flavonoid tricin seems to be specially recalcitrant since its content (referred to lignin) was twofold higher after the fungal treatment (passing from 8 to $22 \%$ ). Some changes in the xylan signals were also observed on both wheat straw and poplar wood, including the presence of stronger anomeric correlations $\left(\alpha / \beta \mathrm{X}_{1(\mathrm{R})}\right)$ corresponding to reducing ends.

\section{Discussion}

\section{Secretomes of lignocellulose-decaying basidiomycetes}

Studies on the proteome of wood-rotting basidiomycetes have increased during the last years in parallel with the increasing number of sequenced genomes, which enabled protein identification by tandem mass spectrometry using genomic databases (such as JGI Mycocosm). Since wood (and lignin polymer) decay is necessarily an extracellular process [35], secreted proteins have been generally analyzed in these studies.

P. chrysosporium was the first basidiomycete whose secretome was studied in carbon- and nitrogen-limited glucose media, and using/adding more complex carbon sources in/to liquid media, such as: (i) microcrystalline cellulose [36-38]; (ii) milled poplar wood [39, 40]; (iii) xylan/starch [41]; (iv) technical lignin [42]; and (v) other lignocellulosic substrates [43] (the two latter studies using quantitative proteomic techniques). The $P$. chrysosporium secretome was also analyzed during solid-state fermentation (SSF) of red oak wood [44, 45], black pine wood [46], and wheat straw [47].

Other white-rot fungi whose secretomes have been analyzed are: (i) Pleurotus sapidus growing in submerged and SSF lignocellulose cultures [48, 49]; (ii) Phanerochaete carnosa growing on microcrystalline cellulose in liquid medium, and on spruce chips under SSF conditions (compared with P. chrysosporium) [50]; (iii) Ganoderma lucidum during SSF of sugarcane bagasse [51]; (iv) Trametes trogii growing on poplar wood blocks [52]; (v) Irpex lacteus during wheat straw SSF [53] (compared with P. chrysosporium and P. ostreatus); (vi) C. subvermispora growing in liquid medium with microcrystalline cellulose and milled aspen (compared with P. chrysosporium) [6, 54]; (vii) Phlebiopsis gigantea growing on aspen and pine wood wafers [12]; and (viii) Pycnoporus cinnabarinus in (ligno)cellulose supplemented maltose liquid cultures, and as a SSF mixed secretome (from cultures on five different plant substrates) [13].

The secretomes of other lignocellulose-decaying basidiomycetes were also analyzed, including: (i) the brownrotters $P$. placenta in liquid medium with cellulose or aspen/pine wood (compared with $P$. chrysosporium) [5, 39,55 ] and colonizing poplar chips on malt agar [56], and Serpula lacrymans growing on pine wood [57]; and 
(ii) the coprophilous $C$. cinerea growing in glucose-peptone-yeast extract medium [58]. Finally, general comparisons of basidiomycete secretomes-including additional eleven white-rot and four brown-rot species and some poor wood decayers (such as Schizophyllum commune)have been reported using milled-aspen liquid medium, with special emphasis on CAZy proteins $[9,11]$.

\section{Global analysis of the $P$. ostreatus secretome}

A total of 508 different proteins were identified in the secretome of $P$. ostreatus growing with poplar wood, wheat straw, and glucose as carbon sources. This number is higher than reported in most of the studies cited above, which included up to 356 secreted proteins for $P$. chrysosporium and 413 proteins for $P$. placenta growing in glucose, aspen, and pine media [55], 168 proteins for a different (dikaryotic) P. ostreatus strain (during SSF of wheat straw) [53], and only 18 proteins in an early study of the P. sapidus secretome [48]. A higher number of basidiomycete-secreted proteins (near eight-hundred) were only reported in a recent secretomic study of $P$. chrysosporium growing on wood from three different poplar genotypes [40].

The secretome of $P$. ostreatus strongly varied, with only $20 \%$ of the proteins being common to the three cultures analyzed. Interestingly, a similar additional percentage (19\%) was shared by the straw and poplar cultures, while the glucose culture only shared 2 and $4 \%$ proteins with the poplar and wheat-straw cultures, respectively, revealing a strong and common effect of lignocellulose on the secreted proteins. More than half of the proteins were present only in one of the cultures, including $34 \%$ on wheat straw, $15 \%$ on glucose, and (only) $6 \%$ on poplar wood. This reveals that colonization of wheat straw requires a high number of unique proteins in addition to those shared with the poplar culture (and the $20 \%$ common to the three growth conditions). Moreover, strong differential production was observed for some of the shared proteins, as discussed below.

The above differences were analyzed considering the relative numbers and abundances of the main protein types. Most of them corresponded to the groups of oxidoreductases, CAZys (including plant cellulose/hemicellulose/pectin and fungal cell-wall degrading enzymes) or unknown function proteins, with the three types showing similar diversities (protein numbers) in the poplar and straw secretomes. However, in the HAT medium the diversity of CAZys was higher, although no (ligno)cellulosic substrate was present.

The differences are more remarkable when the abundances of each of the proteins were considered. In this way, it was shown that oxidoreductases (including LMEs), are by large the most abundant proteins in the two lignocellulose cultures, and less abundant in the glucose medium, where proteases and unknown proteins had larger, and CAZy slightly lower, abundances than in the lignocellulose cultures. Moreover, noteworthy differences in the different oxidoreductase "superfamilies" were observed, with peroxidases and especially multicopper oxidases (laccases) being abundant in the lignocellulose cultures but nearly absent from the glucose medium, where other oxidoreductases (including different oxidases) were more abundant. The unknown proteins, whose abundance was emphasized in early studies on wood-rotting fungal secretomes [38], still represent an important challenge in the present secretomic studies. Concerning glucose medium, the presence of soluble peptides (from yeast extract and casamino acids) is most probably related to the high protease levels observed. Moreover, the higher abundance of secreted proteins in the glucose cultures ( 6000 total PSM, compared with 4000-5000 total PSM in the lignocellulose cultures) is most probably due to the shaken conditions used (compared with stationary lignocellulosic cultures) that promote protein secretion, as reported for example for extracellular chitinases [59].

\section{CAZy proteins in the $P$. ostreatus secretomes}

Seven CAZy families (GH15, GH47, GH3, GH76, GH1, $\mathrm{CE16}$, and GH105) were among the top-50 proteins in the $P$. ostreatus secretomes, but only one of them (CE16 acetylesterase) was clearly overproduced on lignocellulose (with respect to the glucose medium). When the woody and nonwoody lignocellulosic secretomes were compared, GH1 and GH3 (two $\beta$-glycosidases) were significantly more abundant in the poplar and wheat straw cultures, respectively. Among less abundant proteins, GH51 and GH35 were also more represented in wheat straw. Interestingly, the first CAZy in the top-50 proteins is glucoamylase GH15, being secreted in the three culture media. All the above CAZy families have been reported in the secretomes of other white-rot fungi growing under liquid and SSF conditions, several of them (e.g., GH3, $\mathrm{GH} 5$ or GH10) being overproduced in the presence of lignocellulosic substrates [12, 13, 38-40, 43, 50, 53].

Most families of "bulk carbohydrate" CAZys acting on polysaccharide backbones (such as GH5, GH6, GH7, GH10, and GH28) were found in the P. ostreatus secretomes, often represented by different proteins. However, the most abundant CAZys detected (such as GH1, GH3, and CE16) belong to the so-called "accessory" CAZy families, with GH51 endoglucanase/endoxylanase being the exception (1\% abundance in the wheat straw secretome). The above contrasts with other studies where endo-cellulases/xylanases (e.g., family GH10) are among the main proteins secreted by white-rot basidiomycetes 
(e.g., P. chrysosporium, P. gigantea, or C. subvermispora) when growing in wood-containing media [12, 40, 54]. The low levels of "cellulases" (from the GH5, GH6, and GH7 families) could be related to the selective degradation of lignin reported by some Pleurotus species [17]. On the other hand, no lytic polysaccharide monooxygenase (LPMO, former GH61 family) nor cellobiose dehydrogenase $(\mathrm{CDH})$ proteins were detected in the secretome of $P$. ostreatus under the present growth conditions, although $18 \mathrm{LPMO}$ and $1 \mathrm{CDH}$ genes were annotated in the (PC9) genome. This contrast with the important role attributed to these enzymes, acting synergistically in cellulose degradation by some fungal species [60].

In addition to the above CAZys involved in degradation of plant polysaccharides, at least 28 CAZy proteins putatively contributing to the autolysis of fungal cell wall were identified. Seventy-five percent of them belong to families GH16 and GH18 (involved in $\beta$-glucan and chitin degradation, respectively) but members of the GH13, GH30 and GH72 families were also present. Chitinases (GH18) and $\beta$-glucanases (GH16) have been identified in the secretomes of other basidiomycetes $[5,11,38,43,61]$. Their diversity in the P. ostreatus secretome (GH18 was the CAZy family with the highest protein number) could be related to the need of recycling nutrients (by hyphal autolysis) in 3-week-old cultures. Hyphal lysis would be also related to the high levels of proteases involved in nitrogen recycling, as reported in the $P$. chrysosporium secretome [38].

\section{LMEs and other oxidoreductase proteins in the $P$. ostreatus secretomes}

The $P$. ostreatus genome includes at least ten laccase genes $[15,25]$, together with seventeen peroxidase genes corresponding to one class-I peroxidase, nine class-II peroxidases, three heme-thiolate peroxidases (HTPs), and four DyPs [62]. After their heterologous expression, the class-II peroxidases have been identified as three VPs (being able to degrade model dimers and depolymerize lignin) and six MnPs (also showing Mn-independent activities) [27]. In parallel, two divergent DyP types have been identified with DyP4 being able to oxidize $\mathrm{Mn}^{2+}$ to $\mathrm{Mn}^{3+}$, as MnPs and VPs do [63]. At least four of the above ten laccases, the three VPs, two of the six MnPs, and DyP4 were secreted by $P$. ostreatus when growing on lignocellulosic substrates, as shown in the present secretomic study. The above results agree with a transcriptomic study of the same fungus [29], as well as with previous biochemical studies reporting enzymatic activities (without identifying the specific genes expressed) in $P$. ostreatus cultures grown on lignocellulosic substrates [64-68].
LACC10 is the main protein in the two lignocellulose secretomes, and LACC2, LACC9, and LACC6 are also among the top-50 proteins, together with VP1, MnP3, DyP4, and other seven oxidoreductases. These four laccases had been previously cloned, and reported as POX1 (LACC9), POX2 (LACC10), POXA1B (LACC6), and POXA3 (LACC2) [69-72]. However, only two peroxidases (VP2 and MnP3) of the five found in the secretome had been previously cloned as two MnPs [73, 74] with veratryl alcohol oxidation by VP2 being reported later [75], and the other enzymes were only known from the genome sequence [27]. Concerning the ligninolytic ability of the above enzymes, only VP has been reported to degrade (non-phenolic) lignin model dimers [27], but it has been also shown that laccases in the presence of redox mediators can perform similar reactions [76] and strongly degrade lignin in lignocellulosic materials [77, $78]$, in agreement with their high abundance in the lignocellulose cultures of $P$. ostreatus.

The above laccases, VP1 and MnP3 were significantly more abundant in the lignocellulose cultures, while oxidases of two different superfamilies-galactose oxidases from the CRO superfamily [79], and several members of the GMC superfamily [30]-were more abundant in the glucose culture. Among less represented proteins, VP2 was overproduced in wheat straw with respect to poplar wood, while VP3 was only found on poplar. It is worth mentioning that the poplar/wheat-straw abundance of LACC10 was one order of magnitude higher than that of the main CAZy protein in the lignocellulose cultures. Unexpectedly, AAO, the best known Pleurotus GMC [80], was a minor protein in the two lignocellulosic secretomes suggesting that other oxidases, such as galactose oxidase [81] occupying the second position among the top-50 proteins (just after LACC10), would contribute in $\mathrm{H}_{2} \mathrm{O}_{2}$ supply to the $P$. ostreatus peroxidases.

Laccases and MnPs have been reported in the secretomes of a series of wood-rotting basidiomycetes, such as C. subvermispora, G. lucidum, I. lacteus, P. ostreatus, S. lacrymans, and T. trogii [6, 51-53, 57]. Interestingly, in agreement with the present results, LACC10 has been reported as the main laccase isoenzyme induced by wheat straw extracts in $P$. ostreatus cultures [82, 83]. The model ligninolytic basidiomycete $P$. chrysosporium represents a remarkable exception to the above enzyme presence in secretomes, due to the absence of laccase genes in its genome [3]. Although some studies failed to detect ligninolytic peroxidases in (ligno)cellulose/lignin containing cultures of $P$. chrysosporium $[42,43]$, the presence of at least six different $P$. chrysosporium $\mathrm{LiP}$ and $\mathrm{MnP}$ isoenzymes has been reported in (carbon or nitrogen limited) glucose and (ligno)cellulose-containing media [38, 39], and 
the presence of LiP proteins was also claimed in SSF cultures [47]. Moreover, secretomic studies on the related $P$. carnosa suggested the presence of $\mathrm{LiP}$ and $\mathrm{MnP}$ in cellulose and wood-containing media [50], although conclusive evidence is still to be provided. Interestingly, one MnP has been reported as the main secreted protein in (3-day-old) wood cultures of C. subvermispora [54], a fungus with up to thirteen MnP genes [84]. In a similar way, VP proteins, which have been proposed to play in Agaricales (where no LiP genes have been still reported) the same role of LiP in Polyporales [27], had been detected in the secretomes of two Pleurotus species, together with several MnPs [48, 53], in agreement with the present results.

The most significant finding of the present secretomic study is the P. ostreatus overproduction of LMEs (including four laccases, one $\mathrm{VP}$, and one $\mathrm{MnP}$ ) when growing in lignocellulose-containing media. Although laccases and peroxidases have been reported in secretomic studies of several white-rot basidiomycetes, as discussed above, the overproduction levels were in most cases much more modest than those found here for P. ostreatus. One exception could be $P$. cinnabarinus that secretes one laccase (JGI-ID\# 8672) as the main protein in some lignocellulose-based liquid and SSF cultures [13]. Another coincidence with the above $P$. cinnabarinus study is the detection of MnP proteins only in the lignocellulosic secretomes supporting their contribution to lignin decay, maybe through peroxidation reactions [85].

\section{Lignocellulose modification by secreted $P$. ostreatus enzymes}

Interestingly, the above oxidoreductase overproduction could be correlated with the chemical modification of the lignocellulosic substrates shown by 2D NMR at the gel state, a new methodology helping lignocellulose pretreatment studies $[33,86]$. These analyses revealed a preferential removal of lignin (estimated from its aromatic signals) with respect to polysaccharides (estimated from the anomeric carbon signals). This removal was accompanied by a decrease in the $S / G$ ratio of the remaining lignin (especially in wheat straw) and by the complete disappearance of some minor substructures that accompany the main $\beta-O-4^{\prime}$ ethers, such as phenylcoumarans in poplar and resinols in wheat straw (estimated by the specific aliphatic signals of their different side chains). The NMR results also show that: (i) syringyl units are easier to be degraded by the fungus, in agreement with their higher methoxylation degree (that lowers their redox potential); and (ii) resinols, and other minor lignin substructures disappeared during the fungal treatment. Lignin modification in the presence, or even in the absence, of added mediators has been reported for both VP [27, 87] and laccase $[78,88]$ using NMR and other techniques.
The HSQC spectra also showed four aromatic compounds that are naturally incorporated to the lignin polymer: (i-ii) tricin and ferulic acid forming ether linkages on wheat straw lignin (by radical condensation as normal monolignols do) $[89,90]$; and (iii-iv) $p$-coumaric and $p$-hydroxybenzoic acids forming ester linkages on the $\mathrm{C} \gamma$-hydroxyl of wheat straw and poplar lignin units, respectively [91, 92]. The changes in the abundances of these compounds suggest that ferulic acid is preferentially removed by the overproduced $P$. ostreatus oxidoreductases with respect to lignin units (and carbohydrates), while $p$-coumaric acid, $p$-hydroxybenzoic acid, and tricin would be more recalcitrant toward the fungal attack. The differences in cinnamic acid removal may be related to the higher methoxylation degree of ferulic compared to $p$-coumaric acid enabling its oxidation by the secretome laccases (and improving peroxidase degradation) [93]. Finally, the appearance of sugar reducing ends in the spectrum of treated wood, and their increased intensities in the spectrum of treated wheat straw suggest a partial depolymerization of polysaccharides by CAZys.

\section{Conclusions}

Although some differences were observed between the two substrates, the secretome of $P$. ostreatus growing both on poplar wood and wheat straw was characterized by a strong overproduction of LMEs with respect to glucose medium. These overproduced oxidoreductases included four laccases (LACC10 being the most abundant among the 434 different extracellular proteins identified in the lignocellulose cultures), one VP and one MnP. In contrast, CAZy proteins only showed slightly higher production in the lignocellulose cultures (with members of the GH15, GH47, GH3, GH76, GH1, CE16, and GH105 families among the top-50 proteins identified in the three secretomes). The above results agreed with the preferential removal of lignin from the two lignocellulosic substrates shown by the ratio between the lignin (aromatic) signals and the carbohydrate (anomeric) signals in the 2D NMR spectra of the whole treated materials at the gel state, which was accompanied by structural modification of the remaining lignin and carbohydrates.

\section{Methods}

\section{$P$. ostreatus strain and genome}

Monokaryotic P. ostreatus PC9 (CECT20311) was used in the present study. This strain was isolated (together with monokaryon PC15) from dikaryotic P. ostreatus N001 (CECT20600) [28]. Its genomic DNA sequence was obtained at JGI in a project coordinated by A.G. Pisabarro (Public University of Navarre, Spain). The resulting $35.6 \mathrm{Mbp}$ assembly is predicted to include 12,206 genes 
(available for searching at http://www.genome.jgi.doe. gov/PleosPC9_1/PleosPC9_1.home.html).

\section{Comparative analysis of secretomes}

Secretomic studies were performed on P. ostreatus cultures in glucose medium and on two different lignocellulosic substrates. Glucose cultures (triplicate) were grown in 1-L shaken (200 rpm) flasks with $200 \mathrm{~mL}$ (surface to volume ratio of $0.7 \mathrm{~cm}^{-1}$ ) of HAT medium [94] containing $10 \mathrm{~g}$ glucose, $0.2 \mathrm{~g} \mathrm{KH}_{2} \mathrm{PO}_{4}, 0.5 \mathrm{~g} \mathrm{MgSO}_{4} .7 \mathrm{H}_{2} \mathrm{O}, 1 \mathrm{~g}$ casamino acids, $1 \mathrm{~g}$ yeast extract, $0.368 \mathrm{~g}$ ammonium tartrate, and $1 \mathrm{~L}$ of distilled water (sterilized at $120{ }^{\circ} \mathrm{C}$ for $20 \mathrm{~min}$ ). Inocula consisted of $15 \mathrm{~mL}$ of homogenized actively growing mycelium from M7GY [82] liquid cultures (200 rpm). Lignocellulose cultures (triplicate) were grown on $10 \mathrm{~g}$ of chopped wheat (Triticum aestivum) straw or extractives-containing debarked poplar (Рориlus alba) small chips (particle size $<4 \mathrm{~mm}$ in both cases) soaked with $70 \mathrm{~mL}$ of distilled water in 1-L flasks (surface to volume ratio of $1.9 \mathrm{~cm}^{-1}$ ) sterilized at $120{ }^{\circ} \mathrm{C}$ for $20 \mathrm{~min}$, incubated under stationary conditions. Inocula consisted of $15 \mathrm{~mL}$ of homogenized mycelium from M7GY cultures. All the above cultures were maintained at $25^{\circ} \mathrm{C}$.

Cultures in the above media were grown for 21 days, triplicates were combined, filtered under vacuum, and the filtrates used for proteomic analyses, while the solid fraction (from the lignocellulose cultures) was used for the chemical analyses described in the next section. Total extracellular proteins in the filtrates were freezedried, resuspended in $10 \mathrm{mM}$ tartrate ( $\mathrm{pH}$ 5), impurities removed by a short polyacrylamide gel electrophoresis run, and stained by Colloidal Blue Kit (Invitrogen). The protein band was cut and destained using $50 \mathrm{mM}$ ammonium bicarbonate in $50 \%$ acetonitrile $(\mathrm{ACN})$, reduced with $10 \mathrm{mM}$ dithiothreitol for $30 \mathrm{~min}$ at $56{ }^{\circ} \mathrm{C}$, alkylated with $55 \mathrm{mM}$ iodoacetamide in the dark for $30 \mathrm{~min}$ at $24{ }^{\circ} \mathrm{C}$, and digested with $12.5 \mathrm{ng} \cdot \mu^{-1}$ trypsin in $50 \mathrm{~mm}$ ammonium bicarbonate, overnight at $30{ }^{\circ} \mathrm{C}$. Peptides were extracted at $37^{\circ} \mathrm{C}$ using $100 \% \mathrm{ACN}$, and then $0.5 \%$ trifluoroacetic acid, dried, cleaned using ZipTip with 0.6 $\mu \mathrm{L} \mathrm{C18}$ resin (Millipore), and reconstituted in $5 \mu \mathrm{L}$ of $0.1 \%$ formic acid in $2 \% \mathrm{ACN}$.

Tryptic peptides were analyzed in an LTQ-Orbitrap Velos mass spectrometer (Thermo Scientific) coupled to a nanoEasy high-performance liquid chromatography equipment (Proxeon). Peptides were first trapped onto a C18-A1 ASY-Column $2 \mathrm{~cm}$ precolumn (Thermo Scientific), and then eluted onto a Biosphere C18 column (75 $\mu \mathrm{m}$ inner diameter, $15 \mathrm{~cm}$ long and $3 \mu \mathrm{m}$ particle size) (NanoSeparations) using a 130 min gradient from 0-45 \% buffer-B (buffer-A: $0.1 \%$ formic acid in $2 \% \mathrm{ACN}$; buffer-B: $0.1 \%$ formic acid in pure $\mathrm{ACN}$ ) at a flow rate of
$250 \mathrm{~nL} \cdot \mathrm{min}^{-1}$. Mass spectra were acquired in the positive ion mode and data dependent manner selecting the 20 most intense ions for fragmentation using CID (collision induced dissociation). MS spectra $(m / z 300-1600)$ were acquired in the Orbitrap with a target value of $1,000,000$ at a resolution of 30,000 (at $\mathrm{m} / \mathrm{z} 400)$ and MS2 spectra were acquired in the linear ion trap with a target value of 10,000 and normalized collision energy of $35 \%$. Precursor ion charge state screening and monoisotopic precursor selection were enabled. Singly charged ions and unassigned charge states were rejected. Dynamic exclusion was enabled with a repeat count of one and exclusion duration of $30 \mathrm{~s}$.

Acquired spectra were searched against the $P$. ostreatus PC9 genomic database, downloaded from JGI (http:// www.genome.jgi.doe.gov/PleosPC9_1/PleosPC9_1. download.html), using Sequest search engine through Proteome Discoverer (version 1.4). As for the search parameters, precursor and fragment mass tolerance were set to $10 \mathrm{ppm}$ and $0.8 \mathrm{Da}$, respectively. Carbamidomethylation of cysteines was set as a fixed modification and oxidation of methionines was set as a dynamic modification. Two missed cleavages were allowed. Identified peptides were validated using Percolator algorithm with a $q$-value threshold of 0.01 . The presence/absence of a signal peptide was predicted with SignalP 4.1 [95].

\section{NMR analyses of lignocellulose modification}

The solid fraction from poplar wood and wheat straw treated with $P$. ostreatus, and from uninoculated controls kept (for 21 days) under the same conditions, were dried in an aeration oven at $65{ }^{\circ} \mathrm{C}$ until stable weight (to estimate weight losses during the treatments). The dried material was grounded in an IKA A10 cutting mill, and finely milled using a Fritsch Pulverisette six planetary mill at $400 \mathrm{rev} \cdot \mathrm{min}^{-1}$ for $5 \mathrm{~h}$ (with $10 \mathrm{~min}$ breaks after every $10 \mathrm{~min}$ of milling) using a $500-\mathrm{mL}$ agate jar and agate ball bearings $(20 \times 20 \mathrm{~mm})$. Lignin content (as Klason lignin) was estimated as the residue after sulfuric acid hydrolysis of the samples according to Tappi test method T222 om-88 [96]. Neutral sugars in the same hydrolysates were analyzed by gas chromatography, after derivatization to their corresponding alditol acetates [97].

For NMR analysis, $100 \mathrm{mg}$ of milled samples were swollen in DMSO- $d_{6}$ and HSQC spectra were acquired at the gel state $[33,86,98]$. A Bruker AVANCE III $500 \mathrm{MHz}$ spectrometer (Karlsruhe, Germany) fitted with a cryogenically cooled $5 \mathrm{~mm}$ TCI gradient probe with inverse geometry (proton coils closet to the sample) was used. The ${ }^{13} \mathrm{C}-{ }^{1} \mathrm{H}$ correlation experiment was an adiabatic HSQC experiment (using Bruker standard pulse sequence 'hsqcetgpsisp.2'; phase-sensitive gradient-edited-2D HSQC using adiabatic pulses for inversion 
and refocusing). Spectra were acquired from 10 to $0 \mathrm{ppm}$ in F2 $\left({ }^{1} \mathrm{H}\right)$ with 1000 data points for an acquisition time of $100 \mathrm{~ms}$, an interscan delay (D1) of $1 \mathrm{~s}, 200$ to $0 \mathrm{ppm}$ in $\mathrm{F} 1\left({ }^{13} \mathrm{C}\right)$ with 256 increments (F1 acquisition time $8 \mathrm{~ms}$ ) of 32 scans. The ${ }^{1} J_{C H}$ used was $145 \mathrm{~Hz}$. Processing used typical matched Gaussian apodization in ${ }^{1} \mathrm{H}$ and a squared cosine bell in ${ }^{13} \mathrm{C}$. The central DMSO peak was used as an internal reference $\left(\delta_{\mathrm{C}} / \delta_{\mathrm{H}} 39.5 / 2.49 \mathrm{ppm}\right)$. The aromatic ${ }^{13} \mathrm{C}-{ }^{1} \mathrm{H}$ correlation signals of the different lignin units were used for estimation of composition in $p$-hydroxyphenyl $(\mathrm{H})$, guaiacyl $(\mathrm{G})$, syringyl $(\mathrm{S})$ and $\mathrm{C}_{\alpha^{-}}$ oxidized syringyl $\left(\mathrm{S}^{\prime}\right)$ units, and the $p$-hydroxybenzoic acid (PB), $p$-coumaric acid (PCA), ferulic acid (FA), and tricin $(\mathrm{T})$ contents were referred to total lignin (estimated as $\left.\mathrm{H}+\mathrm{G}+\mathrm{S}+\mathrm{S}^{\prime}\right)$. The aliphatic ${ }^{13} \mathrm{C}_{\alpha}{ }^{-1} \mathrm{H}_{\alpha}$ correlation signals of the $\beta-\mathrm{O}-4^{\prime}$ ether $(\mathrm{A})$, phenylcoumaran $(\mathrm{B})$, and resinol $(C)$ side chains were used to estimate the relative abundances of the above substructures per aromatic unit. The intensity corrections introduced by the adiabatic pulse program permit us to refer the latter integrals to the previously obtained number of lignin units. Assignment of lignin (and hemicellulose) signals was based on previous wheat straw and hardwood NMR studies [89, 99-102].

\section{Additional files}

Additional file 1. Protein diversity and CAZy and oxidoreductase Venn diagrams in the three P. ostreatus secretomes analyzed.

Additional file 2. Complete lists of proteins identified in the secretome of $P$. ostreatus growing on three different media.

\begin{abstract}
Abbreviations
AAO: aryl-alcohol oxidase; ACN: acetonitrile; CAZy: carbohydrate-active enzyme; CBM: carbohydrate-binding module; $\mathrm{CDH}$ : cellobiose dehydrogenase; CE: carbohydrate esterase; CRO: copper radical oxidases; DyP: dye-decolorizing peroxidase; GH: glycoside hydrolase; GMC: glucose/methanol/choline oxidases/dehydrogenases; HSQC: heteronuclear single-quantum correlation; LACC: laccase; LiP: lignin peroxidase; LME: lignin-modifying enzyme; LPMO: Iytic polysaccharide monooxygenase; MnP: manganese peroxidase; nLC-MS/ MS: nano-liquid chromatography-mass spectrometry/mass spectrometry; NMR: nuclear magnetic resonance; POX: phenol oxidase; PSM: peptide-spectrum match; VP: versatile peroxidase.
\end{abstract}

\section{Authors' contributions}

EFF, AGP, LR, and ATM conceived and designed the experiments. EFF grew the fungus in the different media and extracted de extracellular proteins. MFLL performed the nLC-MS/MS analysis of secretomes, and the search in the $P$. ostreatus genomic database. EFF and FJRD analyzed the secretomic results. AGP and LR contributed to the protein annotation. MPB contributed to lignocellulosic sample characterization. JR and AG were in charge of the NMR analyses. EFF and ATM wrote the paper. All authors contributed to the discussion of results, critically revised the different sections of the manuscript. All authors read and approved the final manuscript.

\section{Author details}

${ }^{1}$ Department of Biotechnology, Delft University of Technology, Julianalaan 136, 2628 BL Delft, The Netherlands. ${ }^{2}$ Centro de Investigaciones Biológicas,
CSIC, Ramiro de Maeztu 9, 28040 Madrid, Spain. ${ }^{3}$ Instituto de Recursos Naturales y Agrobiología de Sevilla, CSIC, PO Box 1052, 41080 Seville, Spain. ${ }^{4}$ Department of Agrarian Production, Universidad Pública de Navarra, 31006, Pamplona, Spain.

\section{Acknowledgements}

This work was supported by the INDOX (KBBE-2013-613549) EU project, the BIO2014-56388-R, AGL2014-53730-R, and AGL2011-30495 projects of the Spanish Ministry of Economy and Competitiveness (MINECO) co-financed by FEDER funds, and the ProteoRed platform of the Spanish Institute of Health Carlos III (ISCIII). The work conducted by the US DOE JGI is supported by the Office of Science of the US DOE under contract number DE-AC02-05CH1 1231. FJR-D thanks a Ramón y Cajal contract of the Spanish MINECO, and JR thanks a contract of the CSIC project 201440E097. Dr. Alicia Prieto (CIB, Madrid) is acknowledged for the monosaccharide composition analyses. We thank Dr. Manuel Angulo (CITIUS, University of Seville) for performing the NMR analyses.

\section{Competing interests}

The authors declare that they have no competing interests.

Received: 14 October 2015 Accepted: 11 February 2016

Published online: 29 February 2016

\section{References}

1. Kersten P, Cullen D. Extracellular oxidative systems of the lignin-degrading basidiomycete Phanerochaete chrysosporium. Fungal Genet Biol. 2007:44:77-87.

2. Martínez AT, Ruiz-Dueñas FJ, Martínez MJ, del Río JC, Gutiérrez A. Enzymatic delignification of plant cell wall: from nature to mill. Curr Opin Biotechnol. 2009;20:348-57.

3. Martinez D, Larrondo LF, Putnam N, Gelpke MD, Huang K, Chapman J, Helfenbein KG, Ramaiya P, Detter JC, Larimer F, Coutinho PM, Henrissat B, Berka R, Cullen D, Rokhsar D. Genome sequence of the lignocellulose degrading fungus Phanerochaete chrysosporium strain RP78. Nat Biotechnol. 2004;22:695-700.

4. Martínez AT, Speranza M, Ruiz-Dueñas FJ, Ferreira P, Camarero S, Guillén F, Martínez MJ, Gutiérrez A, del Río JC. Biodegradation of lignocellulosics: microbiological, chemical and enzymatic aspects of fungal attack to lignin. Int Microbiol. 2005;8:195-204.

5. Martinez D, Challacombe J, Morgenstern I, Hibbett DS, Schmoll M, Kubicek CP, Ferreira P, Ruiz-Dueñas FJ, Martínez AT, Kersten P, Hammel KE, Vanden Wymelenberg A, Gaskell J, Lindquist E, Sabat G, Bondurant SS, Larrondo LF, Canessa P, Vicuña R, Yadav J, Doddapaneni H, Subramanian V, Pisabarro AG, Lavín JL, Oguiza JA, Master E, Henrissat B, Coutinho PM, Harris P, Magnuson JK, et al. Genome, transcriptome, and secretome analysis of wood decay fungus Postia placenta supports unique mechanisms of lignocellulose conversion. Proc Natl Acad Sci USA. 2009;106:1954-9.

6. Fernández-Fueyo E, Ruiz-Dueñas FJ, Ferreira P, Floudas D, Hibbett DS, Canessa P, Larrondo L, James TY, Seelenfreund D, Lobos S, Polanco R, Tello M, Honda Y, Watanabe T, Watanabe T, Ryu JS, Kubicek CP, Schmoll M, Gaskell J, Hammel KE, John FJ St, Vanden Wymelenberg A, Sabat G, Bondurant SS, Syed K, Yadav J, Doddapaneni H, Subramanian V, Lavín $J \mathrm{~L}$, Oguiza JA, et al. Comparative genomics of Ceriporiopisis subvermispora and Phanerochaete chrysosporium provide insight into selective ligninolysis. Proc Natl Acad Sci USA. 2012;109:5458-63.

7. Scott GM, Akhtar M, Lenz MJ, Swaney RE. Engineering, scale-up, and economic aspects of fungal pretreatment of wood chips. In: Young RA, Akhtar M, editors. Environmentally friendly technologies for the pulp and paper industry. Atlanta: TAPPI Press; 1998. p. 341-84.

8. Grigoriev IV, Nordberg H, Shabalov I, Aerts A, Cantor M, Goodstein D, Kuo A, Minovitsky S, Nikitin R, Ohm RA, Otillar R, Poliakov A, Ratnere I, Riley R, Smirnova T, Rokhsar D, Dubchak I. The genome portal of the Department of Energy Joint Genome Institute. Nucleic Acids Res. 2012;40:D26-32.

9. Floudas D, Binder M, Riley R, Barry K, Blanchette RA, Henrissat B, Martínez AT, Otillar R, Spatafora JW, Yadav JS, Aerts A, Benoit I, Boyd A, Carlson A, Copeland A, Coutinho PM, de Vries RP, Ferreira P, Findley K, Foster 
B, Gaskell J, Glotzer D, Górecki P, Heitman J, Hesse C, Hori C, Igarashi K, Jurgens JA, Kallen N, Kersten P, et al. The Paleozoic origin of enzymatic lignin decomposition reconstructed from 31 fungal genomes. Science. 2012;336:1715-9.

10. Ruiz-Dueñas FJ, Lundell T, Floudas D, Nagy LG, Barrasa JM, Hibbett DS, Martínez AT. Lignin-degrading peroxidases in Polyporales: an evolutionary survey based on ten sequenced genomes. Mycologia. 2013;105:1428-44.

11. Hori C, Gaskell J, Igarashi K, Samejima M, Hibbett DS, Henrissat B, Cullen D. Genomewide analysis of polysaccharides degrading enzymes in 11 white- and brown-rot Polyporales provides insight into mechanisms of wood decay. Mycologia. 2013;105:1412-27.

12. Hori C, Ishida T, Igarashi K, Samejima M, Suzuki H, Master E, Ferreira P, Ruiz-Dueñas FJ, Held B, Canessa P, Larrondo LF, Schmoll M, Druzhinina IS, Kubicek CP, Gaskell J, Kersten P, John F St, Glasner JD, Sabat G, BondDurant SS, Khajamohiddin S, Yadav J, Mgbeahuruike AC, Kovalchuk A, Asiegbu FO, Lackner G, Hoffmeister D, Rencoret J, Gutiérrez A, Sun $\mathrm{H}$, et al. Analysis of the Phlebiopsis gigantea genome, transcriptome and secretome gives insight into its pioneer colonization strategies of wood. PLoS Genet. 2014;10(12):e1004759.

13. Levasseur A, Lomascolo A, Chabrol O, Ruiz-Dueñas FJ, Uzan E, Piumi F, Kües U, Ram AFJ, Murat C, Haon M, Benoit I, Arfi Y, Chevret D, Drula E, Kwon MJ, Gouret P, Lesage-Meessen L, Lombard V, Mariette J, Noirot C, Park J, Patyshakuliyeva A, Sigoillot J-C, Wieneger RA, Wösten HAB, Martin F, Coutinho PM, de Vries RP, Martínez AT, Klopp C, et al. The genome of the white-rot fungus Pycnoporus cinnabarinus: a basidiomycete model with a versatile arsenal for lignocellulosic biomass breakdown. BMC Genom. 2014;15:486.

14. Ohm RA, Riley R, Salamov A, Min B, Choi IG, Grigoriev IV. Genomics of wood-degrading fungi. Fungal Genet Biol. 2014;72:82-90.

15. Riley R, Salamov AA, Brown DW, Nagy LG, Floudas D, Held BW, Levasseur A, Lombard V, Morin E, Otillar R, Lindquist EA, Sun H, LaButti KM, Schmutz J, Jabbour D, Luo H, Baker SE, Pisabarro AG, Walton JD, Blanchette RA, Henrissat B, Martin F, Cullen D, Hibbett DS, Grigoriev IV. Extensive sampling of basidiomycete genomes demonstrates inadequacy of the white-rot/brown-rot paradigm for wood decay fungi. Proc Natl Acad Sci USA. 2014;111:9923-8.

16. Sánchez C. Cultivation of Pleurotus ostreatus and other edible mushrooms. Appl Microbiol Biotechnol. 2010;85:1321-37.

17. Martínez AT, Camarero S, Guillén F, Gutiérrez A, Muñoz C, Varela E, Martínez MJ, Barrasa JM, Ruel K, Pelayo M. Progress in biopulping of non-woody materials: chemical, enzymatic and ultrastructural aspects of wheat-straw delignification with ligninolytic fungi from the genus Pleurotus. FEMS Microbiol Rev. 1994;13:265-74.

18. Camarero S, Barrasa JM, Pelayo M, Martínez AT. Evaluation of Pleurotus species for wheat-straw biopulping. J Pulp Paper Sci. 1998;24:197-203.

19. Salvachúa D, Prieto A, Lopez-Abelairas M, Lú-Chau T, Martínez AT, Martínez MJ. Fungal pretreatment: an alternative in second-generation ethanol from wheat straw. Bioresource Technol. 2011;102:7500-6.

20. Ragauskas AJ, Williams CK, Davison BH, Britovsek G, Cairney J, Eckert CA, Frederick WJ, Hallett JP, Leak DJ, Liotta CL, Mielenz JR, Murphy R, Templer R, Tschaplinski T. The path forward for biofuels and biomaterials. Science. 2006;311:484-9.

21. Stajich JE, Wilke SK, Ahren D, Au CH, Birren BW, Borodovsky M, Burns C, Canbäck B, Casselton LA, Cheng CK, Deng JX, Dietrich FS, Fargo DC, Farman ML, Gathman AC, Goldberg J, Guigo R, Hoegger PJ, Hooker JB, Huggins A, James TY, Kamada T, Kilaru S, Kodira C, Kües U, Kupfert D, Kwan HS, Lomsadze A, Li WX, Lilly WW, et al. Insights into evolution of multicellular fungi from the assembled chromosomes of the mushroom Coprinopsis cinerea (Coprinus cinereus). Proc Natl Acad Sci USA. 2010;107:11889-94.

22. Morin E, Kohler A, Baker AR, Foulongne-Oriol M, Lombard V, Nagy LG, Ohm RA, Patyshakuliyeva A, Brun A, Aerts AL, Bailey AM, Billette C, Coutinho PM, Deakin G, Doddapaneni H, Floudas D, Grimwood J, Hildén K, Kües U, LaButti KM, Lapidus A, Lindquist EA, Lucas SM, Murat C, Riley RW, Salamov AA, Schmutz J, Subramanian V, Wösten HAB, Xu $J$, et al. Genome sequence of the button mushroom Agaricus bisporus reveals mechanisms governing adaptation to a humic-rich ecological niche. Proc Natl Acad Sci USA. 2012;109:17501-6.

23. Doddapaneni H, Subramanian V, Fu B, Cullen D. A comparative genomic analysis of the oxidative enzymes potentially involved in lignin degradation by Agaricus bisporus. Fungal Genet Biol. 2013;55:22-31.

24. Martin F, Aerts A, Ahren D, Brun A, Danchin EGJ, Duchaussoy F, Gibon J, Kohler A, Lindquist E, Pereda V, Salamov A, Shapiro HJ, Wuyts J, Blaudez D, Buée M, Brokstein P, Canbäck B, Cohen D, Courty PE, Coutinho PM Delaruelle C, Detter JC, Deveau A, DiFazio S, Duplessis S, FraissinetTachet L, Lucic E, Frey-Klett P, Fourrey C, Feussner I, et al. The genome of Laccaria bicolor provides insights into mycorrhizal symbiosis. Nature. 2008:452:88-92.

25. Floudas D, Held BW, Riley R, Nagy LG, Koehler G, Ransdell AS, Younus H, Chow J, Chiniqui J, Lipzen A, Tritt A, Sun H, Haridas S, LaButti K, Ohm RA, Kües U, Blanchette RA, Grigoriev IV, Minto RE, Hibbett DS. Evolution of novel wood decay mechanisms in agaricales revealed by the genome sequences of Fistulina hepatica and Cylindrobasidium torrendii. Fungal Genet Biol. 2015;76:78-92.

26. Fernández-Fueyo E, Acebes S, Ruiz-Dueñas FJ, Martínez MJ, Romero A, Medrano FJ, Guallar V, Martínez AT. Structural implications of the C-terminal tail in the catalytic and stability properties of manganese peroxidases from ligninolytic fungi. Acta Crystallogr D Biol Crystallogr. 2014;70:3253-65.

27. Fernández-Fueyo E, Ruiz-Dueñas FJ, Martínez MJ, Romero A, Hammel $\mathrm{KE}$, Medrano FJ, Martínez AT. Ligninolytic peroxidase genes in the oyster mushroom genome: heterologous expression, molecular structure, catalytic and stability properties and lignin-degrading ability. Biotechnol Biofuels. 2014;7:2.

28. Larraya LM, Pérez G, Peñas MM, Baars JJP, Mikosch TSP, Pisabarro AG, Ramírez L. Molecular karyotype of the white rot fungus Pleurotus ostreatus. Appl Environ Microbiol. 1999:65:3413-7.

29. Fernández-Fueyo E, Castanera R, Ruiz-Dueñas FJ, López-Lucendo MF, Ramírez L, Pisabarro AG, Martínez AT. Ligninolytic peroxidase gene expression by Pleurotus ostreatus: differential regulation in lignocellulose medium and effect of temperature and $\mathrm{pH}$. Fungal Genet Biol. 2014;72:150-61.

30. Ferreira P, Carro J, Serrano A, Martínez AT. A survey of genes encoding H2O2-producing GMC oxidoreductases in 10 Polyporales genomes. Mycologia. 2015;107:1105-19.

31. Alfaro M, Oguiza JA, Ramírez L, Pisabarro AG. Comparative analysis of secretomes in basidiomycete fungi. J Proteomics. 2014;102:28-43.

32. Benoit I, Culleton H, Zhou M, DiFalco M, Aguilar-Osorio G, Battaglia E, Bouzid O, Brouwer CPJM, El Bushari HBO, Coutinho PM, Gruben BS, Hildén KS, Houbraken J, Barboza LAJ, Levasseur A, Majoor E, Mäkelä MR, Narang HM, Trejo-Aguilar B, van den Brink J, vanKuyk PA, Wiebenga A, McKie V, McCleary B, Tsang A, Henrissat B, de Vries RP. Closely related fungi employ diverse enzymatic strategies to degrade plant biomass. Biotechnol Biofuels. 2015;8:1-14

33. Rencoret J, Marques G, Gutiérrez A, Nieto L, Santos I, Jiménez-Barbero J, Martínez AT, del Río JC. HSQC-NMR analysis of lignin in woody (Eucalyptus globulus and Picea abies) and non-woody (Agave sisalana) ballmilled plant materials at the gel state. Holzforschung. 2009;63:691-8.

34. Levasseur A, Drula E, Lombard V, Coutinho PM, Henrissat B. Expansion of the enzymatic repertoire of the CAZy database to integrate auxiliary redox enzymes. Biotechnol Biofuels. 2013;6:41.

35. Ruiz-Dueñas FJ, Martínez AT. Microbial degradation of lignin: how a bulky recalcitrant polymer is efficiently recycled in nature and how we can take advantage of this. Microbial Biotechnol. 2009;2:164-77.

36. Vanden Wymelenberg A, Sabat G, Martinez D, Rajangam AS, Teeri TT, Gaskell J, Kersten PJ, Cullen D. The Phanerochaete chrysosporium secretome: database predictions and initial mass spectrometry peptide identifications in cellulose-grown medium. J Biotechnol. 2005;118:17-34.

37. Vanden Wymelenberg A, Minges P, Sabat G, Martinez D, Aerts A, Salamov A, Grigoriev I, Shapiro H, Putnam N, Belinky P, Dosoretz C, Gaskell J, Kersten P, Cullen D. Computational analysis of the Phanerochaete chrysosporium v2.0 genome database and mass spectrometry identification of peptides in ligninolytic cultures reveal complex mixtures of secreted proteins. Fungal Genet Biol. 2006;43:343-56.

38. Vanden Wymelenberg A, Gaskell J, Mozuch M, Kersten P, Sabat G, Martinez D, Cullen D. Transcriptome and secretome analyses of Phanerochaete chrysosporium reveal complex patterns of gene expression. Appl Environ Microbiol. 2009;75:4058-68. 
39. Vanden Wymelenberg A, Gaskell J, Mozuch M, Sabat G, Ralph J, Skyba O, Mansfield SD, Blanchette RA, Martinez D, Grigoriev I, Kersten PJ, Cullen D. Comparative transcriptome and secretome analysis of wood decay fungi Postia placenta and Phanerochaete chrysosporium. Appl Environ Microbiol. 2010;76:3599-610.

40. Gaskell J, Marty A, Mozuch M, Kersten PJ, Bondurant SS, Sabat G, Azarpira A, Ralph J, Skyba O, Mansfield SD, Blanchette RA, Cullen D. Influence of Populus genotype on gene expression by the wood decay fungus Phanerochaete chrysosporium. Appl Environ Microbiol. 2014;80:5828-35.

41. Hori C, Igarashi K, Katayama A, Samejima M. Effects of xylan and starch on secretome of the basidiomycete Phanerochaete chrysosporium grown on cellulose. FEMS Microbiol Lett. 2011;321:14-23.

42. Manavalan A, Adav SS, Sze SK. iTRAQ-based quantitative secretome analysis of Phanerochaete chrysosporium. J Proteomics. 2011;75:642-54

43. Adav SS, Ravindran A, Sze SK. Quantitative proteomic analysis of lignocellulolytic enzymes by Phanerochaete chrysosporium on different lignocellulosic biomass. J Proteomics. 2012;75:1493-504.

44. Abbas A, Koc H, Liu F, Tien M. Fungal degradation of wood: initial proteomic analysis of extracellular proteins of Phanerochaete chrysosporium grown on oak substrate. Curr Genet. 2005;47:49-56.

45. Sato S, Liu F, Koc H, Tien M. Expression analysis of extracellular proteins from Phanerochaete chrysosporium grown on different liquid and solid substrates. Microbiology-Sgm. 2007;153:3023-33.

46. Ravalason H, Jan G, Molle D, Pasco M, Coutinho PM, Lapierre C, Pollet B, Bertaud F, Petit-Conil M, Grisel S, Sigoillot JC, Asther M, HerpoëlGimbert I. Secretome analysis of Phanerochaete chrysosporium strain CIRM-BRFM41 grown on softwood. Appl Microbiol Biotechnol. 2008;80:719-33

47. Singh D, Zeng JJ, Laskar DD, Deobald L, Hiscox WC, Chen SL. Investigation of wheat straw biodegradation by Phanerochaete chrysosporium. Biomass Bioenergy. 2011:35:1030-40.

48. Zorn H, Peters T, Nimtz M, Berger RG. The secretome of Pleurotus sapidus. Proteomics. 2005:5:4832-8.

49. Bouws $H$, Wattenberg A, Zorn H. Fungal secretomes-nature's toolbox for white biotechnology. Appl Microbiol Biotechnol. 2008;80:381-8.

50. Mahajan S, Master ER. Proteomic characterization of lignocellulosedegrading enzymes secreted by Phanerochaete carnosa grown on spruce and microcrystalline cellulose. Appl Microbiol Biotechnol. 2010;86:1903-14.

51. Manavalan T, Manavalan A, Thangavelu KP, Heese K. Secretome analysis of Ganoderma lucidum cultivated in sugarcane bagasse. J Proteomics. 2012;77:298-309.

52. Ji XL, Zhang WT, Gai YP, Lu BY, Yuan CZ, Liu QX, Mu ZM. Patterns of lignocellulose degradation and secretome analysis of Trametes trogii MT. Int Biodeterior Biodegradation. 2012;75:55-62.

53. Salvachúa D, Martínez AT, Tien M, López-Lucendo MF, García F, de los Ríos V, Martínez MJ, Prieto A. Differential proteomic analysis of the secretome of Irpex lacteus and other white-rot fungi during wheat straw pretreatment. Biotechnol Biofuels. 2013:6:115

54. Hori C, Gaskell J, Igarashi K, Kersten P, Mozuch M, Samejima M, Cullen D. Temporal alterations in the secretome of the selective ligninolytic fungus Ceriporiopsis subvermispora during growth on aspen wood reveal this organism's strategy for degrading lignocellulose. Appl Environ Microbiol. 2014;80:2062-70.

55. Vanden Wymelenberg A, Gaskell J, Mozuch M, Bondurant SS, Sabat G, Ralph J, Skyba O, Mansfield SD, Blanchette RA, Grigoriev IV, Kersten PJ, Cullen D. Significant alteration of gene expression in wood decay fungi Postia placenta and Phanerochaete chrysosporium by plant species. Appl Environ Microbiol. 2011;77:4499-507.

56. Ryu JS, Shary S, Houtman CJ, Panisko EA, Korripally P, John FJS, Crooks C, Siika-aho M, Magnuson JK, Hammel KE. Proteomic and functional analysis of the cellulase system expressed by Postia placenta during brown rot of solid wood. Appl Environ Microbiol. 2011;77:7933-41.

57. Eastwood DC, Floudas D, Binder M, Majcherczyk A, Schneider P, Aerts A, Asiegbu FO, Baker SE, Barry K, Bendiksby M, Blumentritt M, Coutinho PM, Cullen D, de Vries RP, Gathman A, Goodell B, Henrissat B, Ihrmark K, Kauserud H, Kohler A, LaButti K, Lapidus A, Lavin JL, Lee YH, Lindquist E, Lilly W, Lucas S, Morin E, Murat C, Oguiza JA, et al. The plant cell wall-decomposing machinery underlies the functional diversity of forest fungi. Science. 2011;333:762-5.

58. Hoegger P, Majcherczyk A, Dwivedi R, Svobodova K, Kilaru S, Kües U. Enzymes in wood degradation. In: Kües U, editor. Wood production, wood technology and biotechnological impacts. Göttingen: Universtätsverlag Göttingen; 2007. p. 383-432.

59. Liu BL, Kao PM, Tzeng YM, Feng KC. Production of chitinase from Verticillium lecanii F091 using submerged fermentation. Enzyme Microb Technol. 2003;33:410-5.

60. Phillips CM, Beeson WT, Cate JH, Marletta MA. Cellobiose dehydrogenase and a copper-dependent polysaccharide monooxygenase potentiate cellulose degradation by Neurospora crassa. ACS Chem Biol. 2011:6:1399-406.

61. Veneault-Fourrey C, Commun C, Kohler A, Morin E, Balestrini R, Plett J, Danchin E, Coutinho P, Wiebenga A, de Vries RP, Henrissat B, Martin F. Genomic and transcriptomic analysis of Laccaria bicolor CAZome reveals insights into polysaccharides remodelling during symbiosis establishment. Fungal Genet Biol. 2014;72:168-81.

62. Ruiz-Dueñas FJ, Fernández E, Martínez MJ, Martínez AT. Pleurotus ostreatus heme peroxidases: an in silico analysis from the genome sequence to the enzyme molecular structure. C R Biol. 2011;334:795-805.

63. Fernández-Fueyo E, Linde D, Almendral D, López-Lucendo MF, RuizDueñas FJ, Martínez AT. Description of the first fungal dye-decolorizing peroxidase oxidizing manganese(II). Appl Microbiol Biotechnol. 2015;99:8927-42.

64. Camarero S, Martínez MJ, Martínez AT. Lignin-degrading enzymes produced by Pleurotus species during solid-state fermentation of wheat straw. In: Roussos S, Lonsane BK, Raimbault M, ViniegraGonzález G, editors. Advances in solid state fermentation. Dordrecht: Kluwer Acad. Publ.; 1997. p. 335-45.

65. Singh M, Pandey A, Vishwakarma S, Srivastava A, Pandey V, Singh V. Production of cellulolytic enzymes by Pleurotus species on lignocellulosic wastes using novel pretreatments. Cell Mol Biol. 2014;60:59-63.

66. Pandey A, Vishwakarma S, Srivastava A, Pandey V, Agrawal S, Singh M. Production of ligninolytic enzymes by white rot fungi on lignocellulosic wastes using novel pretreatments. Cell Mol Biol. 2014;60:41-5.

67. Pandey $V$, Singh M. Biodegradation of wheat straw by Pleurotus ostreatus. Cell Mol Biol. 2014;60:29-34.

68. Bánfi R, Pohner Z, Kovács J, Luzics S, Nagy A, Dudás M, Tanos P, Márialigeti K, Vajna B. Characterisation of the large-scale production process of oyster mushroom (Pleurotus ostreatus) with the analysis of succession and spatial heterogeneity of lignocellulolytic enzyme activities. Fungal Biol-UK. 2015;119:1354-63.

69. Giardina P, Cannio R, Martirani L, Marzullo L, Palmieri G, Sannia G. Cloning and sequencing of a laccase gene from the lignin-degrading basidiomycete Pleurotus ostreatus. Appl Environ Microbiol. 1995;61:2408-13.

70. Giardina P, Palmieri G, Scaloni A, Fontanella B, Faraco V, Cennamo G, Sannia G. Protein and gene structure of a blue laccase from Pleurotus ostreatus. Biochem J. 1999;341(655-663):655-63.

71. Giardina P, Autore F, Faraco V, Festa G, Palmieri G, Piscitelli A, Sannia G. Structural characterization of heterodimeric laccases from Pleurotus ostreatus. Appl Microbiol Biotechnol. 2007;75:1293-300

72. Moussa TAA. Molecular characterization of the phenol oxidase (pox2) gene from the ligninolytic fungus Pleurotus ostreatus. FEMS Microbiol Lett. 2009:298:131-42.

73. Giardina P, Palmieri G, Fontanella B, Rivieccio V, Sannia G. Manganese peroxidase isoenzymes produced by Pleurotus ostreatus grown on wood sawdust. Arch Biochem Biophys. 2000;376:171-9.

74. Irie T, Honda Y, Ha H-C, Watanabe T, Kuwahara M. Isolation of CDNA and genomic fragments encoding the major manganese peroxidase isoenzyme from the white rot basidiomycete Pleurotus ostreatus. J Wood Sci. 2000;46:230-3.

75. Kamitsuji H, Honda Y, Watanabe T, Kuwahara M. Production and induction of manganese peroxidase isozymes in a white-rot fungus Pleurotus ostreatus. Appl Microbiol Biotechnol. 2004;65:287-94.

76. Cañas Al, Camarero S. Laccases and their natural mediators: biotechnological tools for sustainable eco-friendly processes. Biotechnol Adv. 2010;28:694-705.

77. Rico A, Rencoret J, del Río JC, Martínez AT, Gutiérrez A. Pretreatment with laccase and a phenolic mediator degrades lignin and enhances saccharification of Eucalyptus feedstock. Biotechnol Biofuels. 2014;7:6. 
78. Gutiérrez A, Rencoret J, Cadena EM, Rico A, Barth D, del Río JC, Martínez AT. Demonstration of laccase-mediator removal of lignin from wood and non-wood plant feedstocks. Bioresource Technol. 2012;119:114-22.

79. Kersten P, Cullen D. Copper radical oxidases and related extracellular oxidoreductases of wood-decay Agaricomycetes. Fungal Genet Biol. 2014;72:124-30.

80. Hernández-Ortega A, Ferreira P, Martínez AT. Fungal aryl-alcohol oxidase: a peroxide-producing flavoenzyme involved in lignin degradation. Appl Microbiol Biotechnol. 2012;93:1395-410.

81. Monti D, Ottolina G, Carrea G, Riva S. Redox reactions catalyzed by isolated enzymes. Chem Rev. 2011;111:4111-40.

82. Castanera R, Pérez G, Omarini A, Alfaro M, Pisabarro AG, Faraco V, Amore A, Ramírez L. Transcriptional and enzymatic profiling of Pleurotus ostreatus laccase genes in submerged and solid-state fermentation cultures. Appl Environ Microbiol. 2012;78:4037-45.

83. Parenti A, Muguerza E, Iroz AR, Omarini A, Conde E, Alfaro M, Castanera R, Santoyo F, Ramirez L, Pisabarro AG. Induction of laccase activity in the white rot fungus Pleurotus ostreatus using water polluted with wheat straw extracts. Bioresource Technol. 2013;133:142-9.

84. Fernández-Fueyo E, Ruiz-Dueñas FJ, Miki Y, Martínez MJ, Hamme KE, Martínez AT. Lignin-degrading peroxidases from genome of selective ligninolytic fungus Ceriporiopsis subvermispora. J Biol Chem. 2012;287:16903-16.

85. Bao WL, Fukushima Y, Jensen KA, Moen MA, Hammel KE. Oxidative degradation of non-phenolic lignin during lipid peroxidation by fungal manganese peroxidase. FEBS Lett. 1994;354:297-300.

86. Kim H, Ralph J. A gel-state 2D-NMR method for plant cell wall profiling and analysis: a model study with the amorphous cellulose and xylan from ball-milled cotton linters. RSC Advances. 2014;4:7549-60.

87. Sáez-Jiménez V, Baratto MC, Pogni R, Rencoret J, Gutiérrez A, Santos J, Martínez AT, Ruiz-Dueñas FJ. Demonstration of lignin-to-peroxidase direct electron transfer: a transient-state kinetics, directed mutagenesis, EPR and NMR study. J Biol Chem. 2015:290:23201-13.

88. Rico A, Rencoret J, del Río JC, Martínez AT, Gutiérrez A. In-depth 2D NMR study of lignin modification during pretreatment of Eucalyptus wood with laccase and mediators. Bioenerg Res. 2015;8:211-30.

89. del Río JC, Rencoret J, Prinsen P, Martínez AT, Ralph J, Gutiérrez A. Structural characterization of wheat straw lignin as revealed by analytical pyrolysis, 2D-NMR, and reductive cleavage methods. J Agric Food Chem. 2012:60:5922-35.
90. Lan W, Lu F, Regner M, Zhu Y, Rencoret J, Ralph SA, Zakai UI, Morreel K, Boerjan W, Ralph J. Tricin, a flavonoid monomer in monocot lignification. Plant Physiology. 2015;167(4):1284-95.

91. Martínez AT, Rencoret J, Marques G, Gutiérrez A, Ibarra D, JiménezBarbero J, del Río JC. Monolignol acylation and lignin structure in some nonwoody plants: a 2D NMR study. Phytochemistry. 2008;69:2831-43.

92. Ralph J. Hydroxycinnamates in lignification. phytochem Rev. 2010;9:65-83.

93. Camarero S, Cañas Al, Nousiainen P, Record E, Lomascolo A, Martínez MJ, Martínez AT. p-Hydroxycinnamic acids as natural mediators for laccase oxidation of recalcitrant compounds. Environ Sci Technol. 2008;42:6703-9.

94. Spinnler HE, de Jong E, Mauvais G, Semon E, Le Quéré J-L. Production of halogenated compounds by Bjerkandera adusta. Appl Microbiol Biotechnol. 1994:42:212-21.

95. Petersen TN, Brunak S, von, Heijne G, Nielsen H, SignalP 4.0: discriminating signal peptides from transmembrane regions. Nat Methods. 2011;8:785-6.

96. Tappi. 2004-2005 TAPPI Test Methods. Norcoss, GA 30092, USA: TAPPI Press; 2004.

97. Laine RA, Esselman WJ, Sweeley CC. Gas-liquid chromatography of carbohydrates. Methods Enzymol. 1972;28:159-67.

98. Kim H, Ralph J, Akiyama T. Solution-state 2D NMR of ball-milled plant cell wall gels in DMSO- $d_{6}$. Bioenerg Res. 2008;1:56-66.

99. Ralph J, Marita JM, Ralph SA, Hatfield RD, Lu F, Ede RM, Peng J, Quideau S, Helm RF, Grabber JH, et al. Solution-state NMR of lignin. In: Argyropoulos DS, editor. Advances in lignocellulosics characterization. Atlanta: Tappi Press; 1999. p. 55-108.

100. Rencoret J, Gutiérrez A, Nieto L, Jiménez-Barbero J, Faulds CB, Kim H, Ralph J, Martínez AT, del Río JC. Lignin composition and structure in young versus adult Eucalyptus globulus plants. Plant Physiol. 2011;155:667-82.

101. Lu FC, Ralph J. Solution-state NMR of lignocellulosic biomass. J Biobased Mater Bio. 2011;5:169-80.

102. Mansfield SD, Kim H, Lu FC, Ralph J. Whole plant cell wall characterization using solution-state 2D NMR. Nat Protoc. 2012;7:1579-89.

\section{Submit your next manuscript to BioMed Central and we will help you at every step:}

- We accept pre-submission inquiries

- Our selector tool helps you to find the most relevant journal

- We provide round the clock customer support

- Convenient online submission

- Thorough peer review

- Inclusion in PubMed and all major indexing services

- Maximum visibility for your research

Submit your manuscript at www.biomedcentral.com/submit
() Biomed Central 